Pacific Northwest

National Laboratory

Operated by Battelle for the

U.S. Department of Energy

\section{Interim-Status RCRA Groundwater Monitoring Plan for the 216-A-10, 216-A-36B, and 216-A-37-1 PUREX Cribs}

\author{
J. W. Lindberg \\ R. P. Elmore
}

July 2005 


\title{
DISCLAIMER
}

This report was prepared as an account of work sponsored by an agency of the United States Government. Reference herein to any specific commercial product, process, or service by trade name, trademark, manufacturer, or otherwise does not necessarily constitute or imply its endorsement, recommendation, or favoring by the United States Government or any agency thereof, or Battelle Memorial Institute.

\author{
PACIFIC NORTHWEST NATIONAL LABORATORY \\ operated by \\ BATTELLE \\ for the \\ UNITED STATES DEPARTMENT OF ENERGY \\ under Contract DE-AC05-76RL01830
}

Printed in the United States of America

Available to DOE and DOE contractors from the

Office of Scientific and Technical Information, P.O. Box 62, Oak Ridge, TN 37831-0062;

prices available from (615) 576-8401

\author{
Available to the public from the National Technical Information Service, \\ U.S. Department of Commerce, 5285 Port Royal Rd., Springfield, VA 22161 \\ ph: (800) 553-6847 \\ fax: (703) 605-6900 \\ email: orders@ntis.fedworld.gov \\ online ordering: http://www.ntis.gov/ordering.htm
}

This document was printed on recycled paper. 


\title{
Interim-Status RCRA Groundwater Monitoring Plan for the 216-A-10, 216-A-36B, and 216-A-37-1 PUREX Cribs
}

\author{
J. W. Lindberg \\ R. P. Elmore
}

July 2005

Prepared for

the U.S. Department of Energy

under Contract DE-AC05-76RL01830

Pacific Northwest National Laboratory

Richland, Washington 99352 


\section{Executive Summary}

This document presents a groundwater monitoring program for three Resource Conservation and Recovery Act of 1976 (RCRA) waste management units at the Hanford Site combined under one groundwater quality assessment program. The units are the 216-A-10, 216-A-36B, and 216-A-37-1 cribs (the RCRA plutonium-uranium extraction [PUREX] cribs). The three cribs have been grouped together based on their proximity to one another, similar construction and waste history, and similar hydrogeologic regime. The RCRA PUREX cribs are located in the 200 East Area of the Hanford Site. This document replaces the previous RCRA monitoring plan (Lindberg 1997) for these cribs. There are other cribs in the 200 East Area that received liquid waste from PUREX Plant operations that are not regulated under RCRA (e.g., 216-A-45 crib). Wells in the vicinity of these cribs are monitored under the 200-PO-1 Groundwater Operable Unit.

The monitoring network comprises near-field wells (wells located in the immediate vicinity of the RCRA PUREX cribs) and far-field wells (wells located farther downgradient). The monitoring strategy for the far-field wells is included in the Sampling and Analysis Plan for the 200-PO-1 Groundwater Operable Unit (DOE-RL 2003). The monitoring strategy for the near-field wells is included in this plan. Near-field wells are listed below.

\begin{tabular}{|c|c|c|}
\hline Well & Near Crib & Up/Down Gradient \\
\hline 299-E17-1 & $216-A-10$ & Down \\
\hline 299-E24-16 & $216-A-10$ & Down \\
\hline $299-E 17-19$ & $216-A-10$ & Down \\
\hline $299-E 17-14$ & $216-A-36 B$ & Down \\
\hline $299-E 17-18$ & $216-A-36 B$ & Down \\
\hline $299-E 17-16$ & $216-A-36 B$ & Down \\
\hline $299-E 25-17$ & $216-A-37-1$ & Down \\
\hline $299-E 25-19$ & $216-A-37-1$ & Down \\
\hline $699-37-47 A$ & $216-A-37-1$ & Down \\
\hline $299-E 24-18$ & $216-A-10$ & Up \\
\hline $299-E 25-31$ & $216-A-37-1$ & Up \\
\hline
\end{tabular}

The near-field wells are sampled either quarterly or semiannually for the following parameters:

Required Constituents, based on WAC 173-303-400 and by reference 40 CFR 265(d)(3) and (d)(4)

Chloride

Iron

Manganese

Sodium

Sulfate

Site-Specific Constituent, based on historical groundwater monitoring at the site

Nitrate 
RCRA groundwater monitoring for the RCRA PUREX cribs is part of the Groundwater Performance Assessment Project. Project staff schedule sampling and initiate paperwork. The project uses subcontractors for sample collection, shipping, and analysis. The groundwater project's quality control program is designed to assess and enhance the reliability and validity of groundwater data. This is accomplished through evaluating the results of quality control samples, conducting audits, and validating groundwater data. 


\section{Contents}

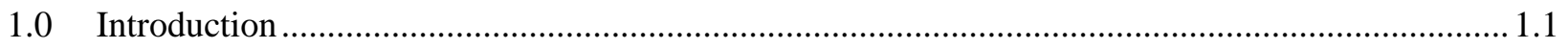

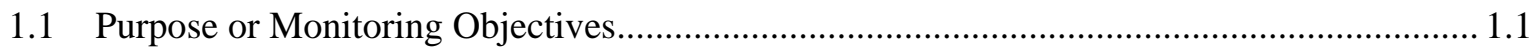

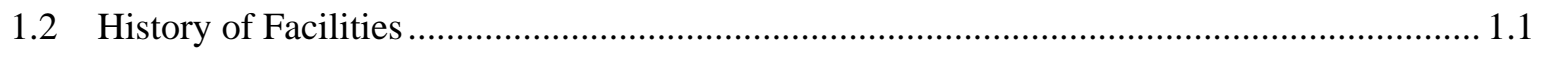

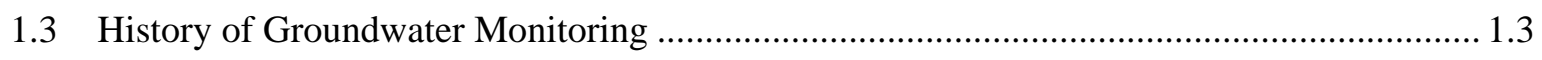

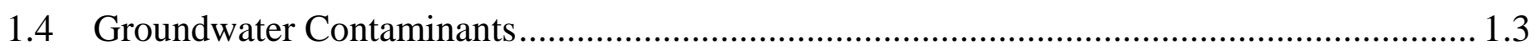

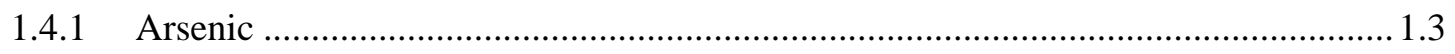

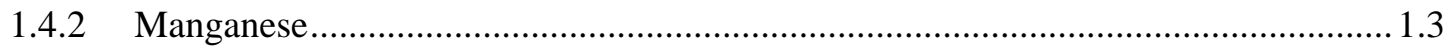

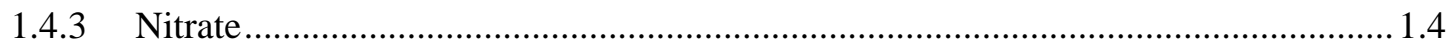

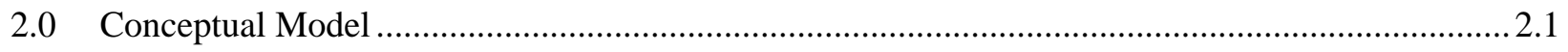

3.0 Groundwater Monitoring Program ...................................................................................... 3.1

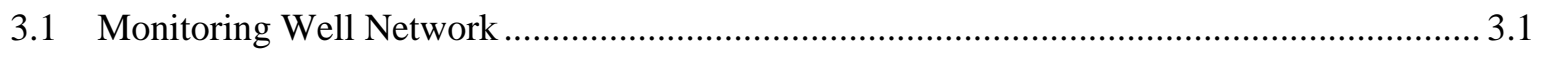

3.2 Constituent List and Sampling Frequency …........................................................... 3.1

3.3 Water Level Monitoring ............................................................................................ 3.2

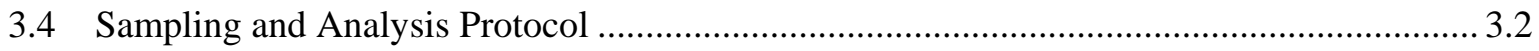

3.4.1 Scheduling Groundwater Sampling..................................................................... 3.3

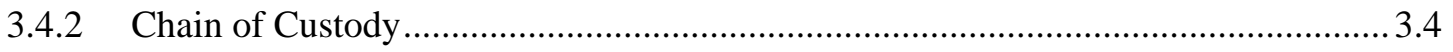

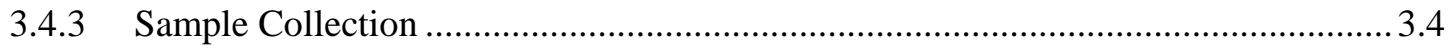

3.4.4 Analytical Protocols ........................................................................................ 3.4

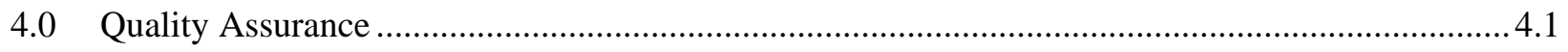

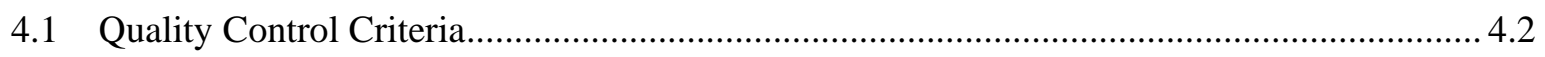

4.2 Groundwater Data Validation Process ............................................................................ 4.3

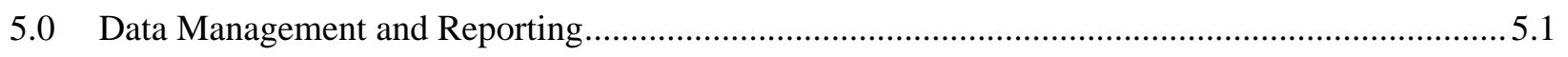

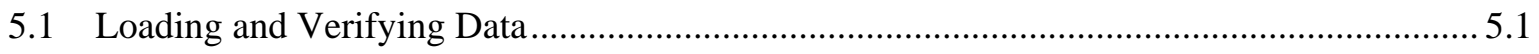

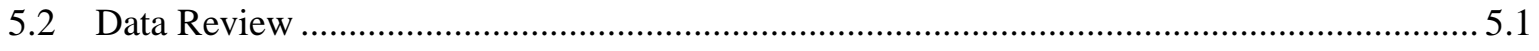

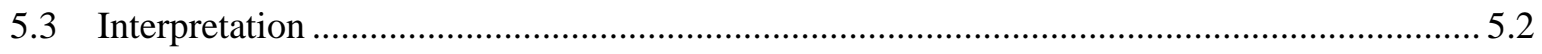

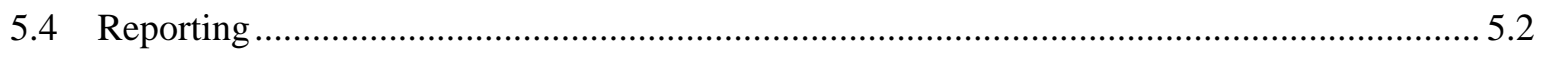

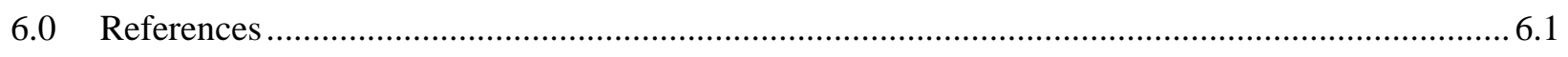

Appendix - As-Built Diagrams of Monitoring Wells..................................................................... A.1 


\section{Figures}

1.1 Near-Field Groundwater Monitoring Wells at the RCRA PUREX Cribs. ..................................... 1.2

1.2 Nitrate Concentration in the Uppermost Aquifer, 200 East Area, October 2004 .......................... 1.5

2.1 Hydrogeologic Conceptual Model Near PUREX Cribs, 200 East Area....................................... 2.2

\section{Tables}

3.1 Wells for RCRA Monitoring at the 216-A-10, 216-A-36B, and 216-A-37-1 PUREX Cribs.......... 3.2

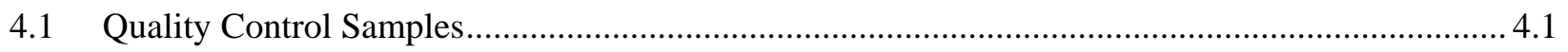

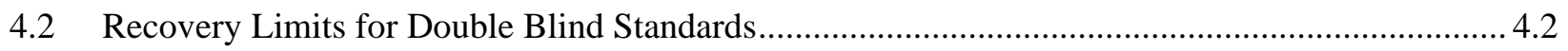




\subsection{Introduction}

This document presents an interim-status, groundwater quality assessment monitoring plan under Resource, Conservation, and Recovery Act of 1976 (RCRA) regulatory requirements found in Washington Administrative Code (WAC) 173-303-400, and by reference requirements in 40 CFR 265(d)(3) and (d)(4), for three RCRA-regulated cribs in the 200 East Area of the Hanford Site: 216-A-10, 216-A-36B, and 216-A-37-1 (the RCRA plutonium-uranium extraction [PUREX] cribs). The RCRA PUREX cribs are part of the 200-PO-1 Operable Unit. This document will replace the previous RCRA monitoring plan (Lindberg 1997) for the RCRA PUREX cribs.

The three RCRA PUREX cribs have been combined into one RCRA waste management area based on their proximity to one another, similar construction, waste history, and hydrogeologic regime. Additionally, their contaminant plumes have merged with time. There are other cribs in the 200-East Area that received liquid waste from PUREX Plant operations that are not regulated under RCRA (e.g., 216-A-45 crib). Wells in the vicinity of these cribs are monitored under the 200-PO-1 Groundwater Operable Unit.

\subsection{Purpose or Monitoring Objectives}

The objective of this monitoring plan is assess the nature, extent, and rate of groundwater contamination migration from the RCRA PUREX cribs until final cleanup decisions are made for the 200-PO-1 Operable Unit. The scope of this RCRA plan is dangerous waste constituents. Radionuclides ${ }^{(a)}$ are monitored under the Atomic Energy Act of 1954 and are included in the 200-PO-1 Operable Unit sampling and analysis plan (DOE-RL 2003).

\subsection{History of Facilities}

The RCRA PUREX cribs (Figure 1.1) are now retired from use. They were used as liquid disposal facilities for the PUREX plant from 1965 to 1989. The 216-A-36B crib received dilute nitric acid and a solution of ammonium fluoride and ammonium nitrate. The waste stream to the 216-A-10 crib was characteristically acidic and contained concentrated salts. Other waste stream constituents included aliphatic hydrocarbon compounds and organic complexants. The A-37-1 crib received spent halogenated and non-halogenated solvents and ammonia. All three cribs received radionuclides ${ }^{(a)}$ (Aldrich 1987). Radionuclides are not monitored under RCRA, thus they are not included in this RCRA monitoring plan. More details about the history of the RCRA PUREX cribs and their waste streams are in Lindberg (1997).

(a) Radionuclides (source, special nuclear, and by-product materials) are monitored in some RCRA unit wells to support objectives of monitoring under the Atomic Energy Act of 1954 (AEA) and/or Comprehensive Environmental Response, Compensation, and Liability Act (CERCLA). Note: pursuant to RCRA, the source, special nuclear, and by-product material components of radioactive mixed waste are not regulated under RCRA and are regulated by the U.S. Department of Energy (DOE) acting pursuant to its AEA authority. Therefore, the inclusion of information on radionuclides in this plan is for information only and may not be used to create conditions or other restrictions set forth in any RCRA permit or other RCRA regulatory requirements. 


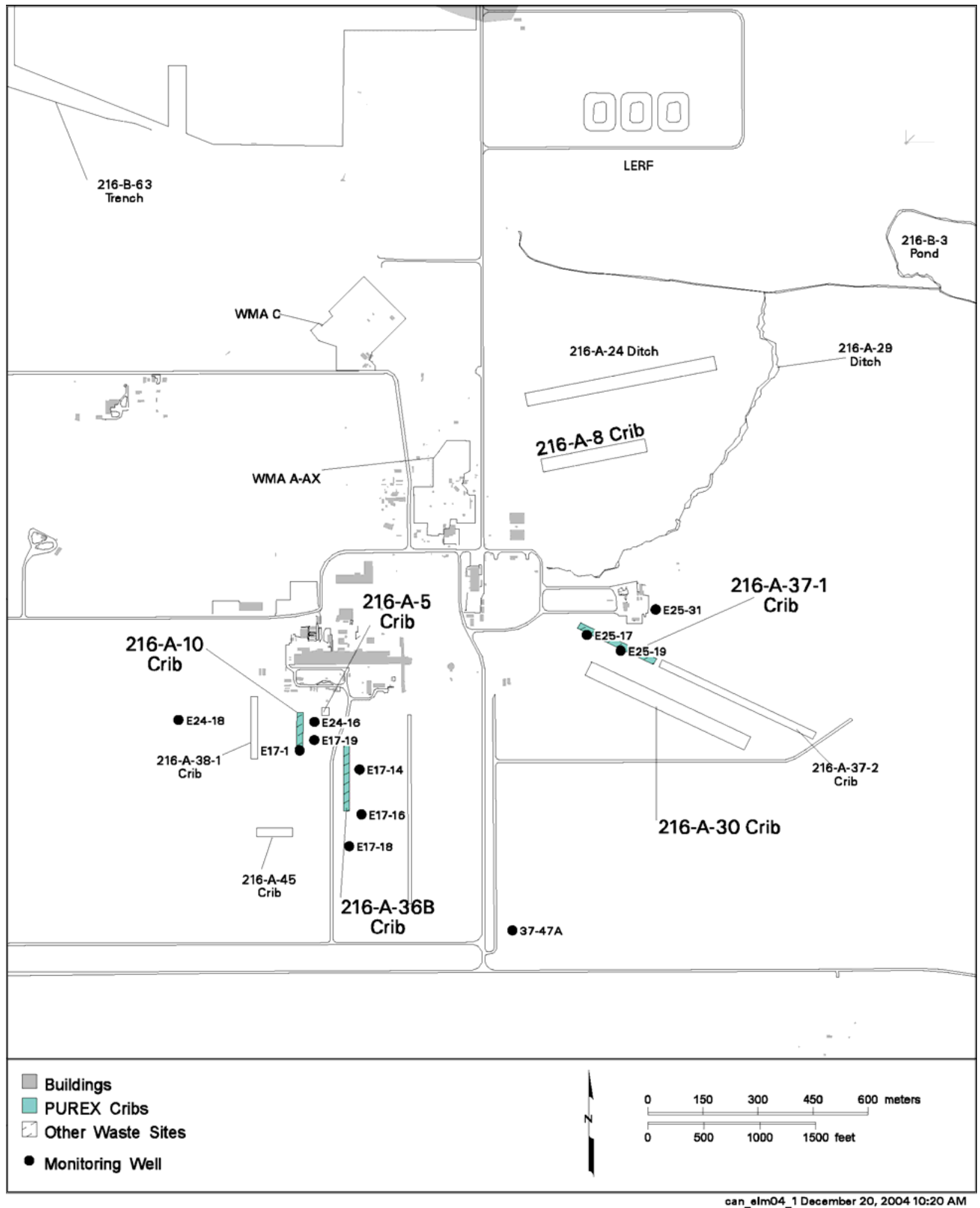

Figure 1.1. Near-Field Groundwater Monitoring Wells at the RCRA PUREX Cribs. 


\subsection{History of Groundwater Monitoring}

Before they were combined into one RCRA monitoring plan in June 1997, the 216-A-10 and 216-A36B cribs were monitored under separate interim-status RCRA programs, and the 216-A-37-1 crib was not monitored under RCRA but was monitored since July 1983 under the Atomic Energy Act of 1954 (AEA).

RCRA groundwater samples were first collected from the 216-A-10 network in November 1988 and from the 216-A-36B network in May 1988 (Kasza 1992). The cribs were sampled for contaminant indicator parameters, groundwater quality parameters, drinking water parameters, and site-specific parameters as required by interim status regulations stipulated in 40 CFR 265. Statistical evaluations of indicator parameter-evaluation data were performed semiannually from 1990 to 1996 (e.g., DOE-RL 1991). The statistical method used was the AR t-test (Chou 1991). The statistical evaluations of the contaminant indicator parameter data did not show that the groundwater quality had been impacted from waste discharged into the 216-A-10 and 216-A-36B cribs, although specific conductance should have been sensitive to elevated nitrate concentration. However, individual constituents (e.g., nitrate) originating from the PUREX cribs have been detected in groundwater and have exceeded drinking water standards.

In 1996 it was recognized that the 216-A-37-1 crib required groundwater monitoring under RCRA. At that time, the three cribs were combined into a single waste management area for groundwater monitoring. Also, because the cribs had contributed to contaminant plumes including nitrate, a groundwater quality assessment program was initiated [40 CFR 265.93(d)].

\subsection{Groundwater Contaminants}

This section discusses source and current concentrations of dangerous waste constituents near the RCRA PUREX cribs. The cribs also contributed to tritium and iodine-129 plumes, which are monitored as part of the 200-PO-1 Operable Unit (DOE-RL 2003).

\subsubsection{Arsenic}

Filtered arsenic continues to be detected in PUREX monitoring wells (e.g., 4 to $10 \mu \mathrm{g} / \mathrm{L}$ ) but in concentrations at or below Hanford groundwater background value of $10 \mu \mathrm{g} / \mathrm{L}$ (DOE-RL 1997). The drinking water standard for arsenic is $10 \mu \mathrm{g} / \mathrm{L}$. Currently, arsenic levels are indistinguishable from background values, but arsenic concentrations are monitored due to a history of elevated values. Before the 1990s, an extensive plume of arsenic was present in the northern and eastern portions of the 200 East Area (WHC 1993). In the eastern portion of the 200 East Area, the sources of arsenic may have been the 216-A-29 ditch, where past discharges of chemical waste were known to include arsenic, or the 216-A37-1 crib, where arsenic was associated with chemical carryover from the 242-A evaporator. The large arsenic plume also included the area in the vicinity of the 216-A-10 and 216-A-36B cribs, where arseniccontaminated wastewater was known to have been discharged.

\subsubsection{Manganese}

Filtered manganese has sporadically exceeded the secondary drinking water standard ( $50 \mu \mathrm{g} / \mathrm{L})$ at two PUREX near-field wells, well 299-E25-19 at the 216-A-37-1 crib and well 299-E17-19 at the 216-A-10 
crib. Although it is possible that manganese-contaminated wastewater was discharged at the PUREX cribs, it is also likely that manganese in these instances is due to corrosion of the well casings or screens. The trend for filtered manganese at the PUREX crib wells is erratic, and elevated levels of manganese are sometimes associated with elevated levels of chromium and nickel, which provide additional evidence that the contamination is due to well-related effects.

\subsubsection{Nitrate}

There are two nitrate plumes in the vicinity of the PUREX cribs (Figure 1.2). One plume is under the 216-A-37-1 crib, where the concentration of nitrate is greater than that detected in surrounding wells but below the $45 \mathrm{mg} / \mathrm{L}$ drinking water standard. The other plume trends northwest to southeast across the southern portion of the 200 East Area. Wells in the immediate vicinity of the 216-A-10 and 216-A-36B cribs show nitrate concentrations that are higher than surrounding wells in this portion of the nitrate plume and exceed the drinking water standard. Well 299-E17-14 (near 216-A-36B crib) has the highest concentration of nitrate near the PUREX cribs. The increased concentration of nitrate in the vicinity of the cribs indicates that 216-A-10 and/or 216-A-36B crib, as well as 216-A-37-1 crib, are a source of nitrate contamination. The nitrate plume has spread east and southeast into the 600 Area of the Hanford Site but concentrations currently are below the drinking water standard. 


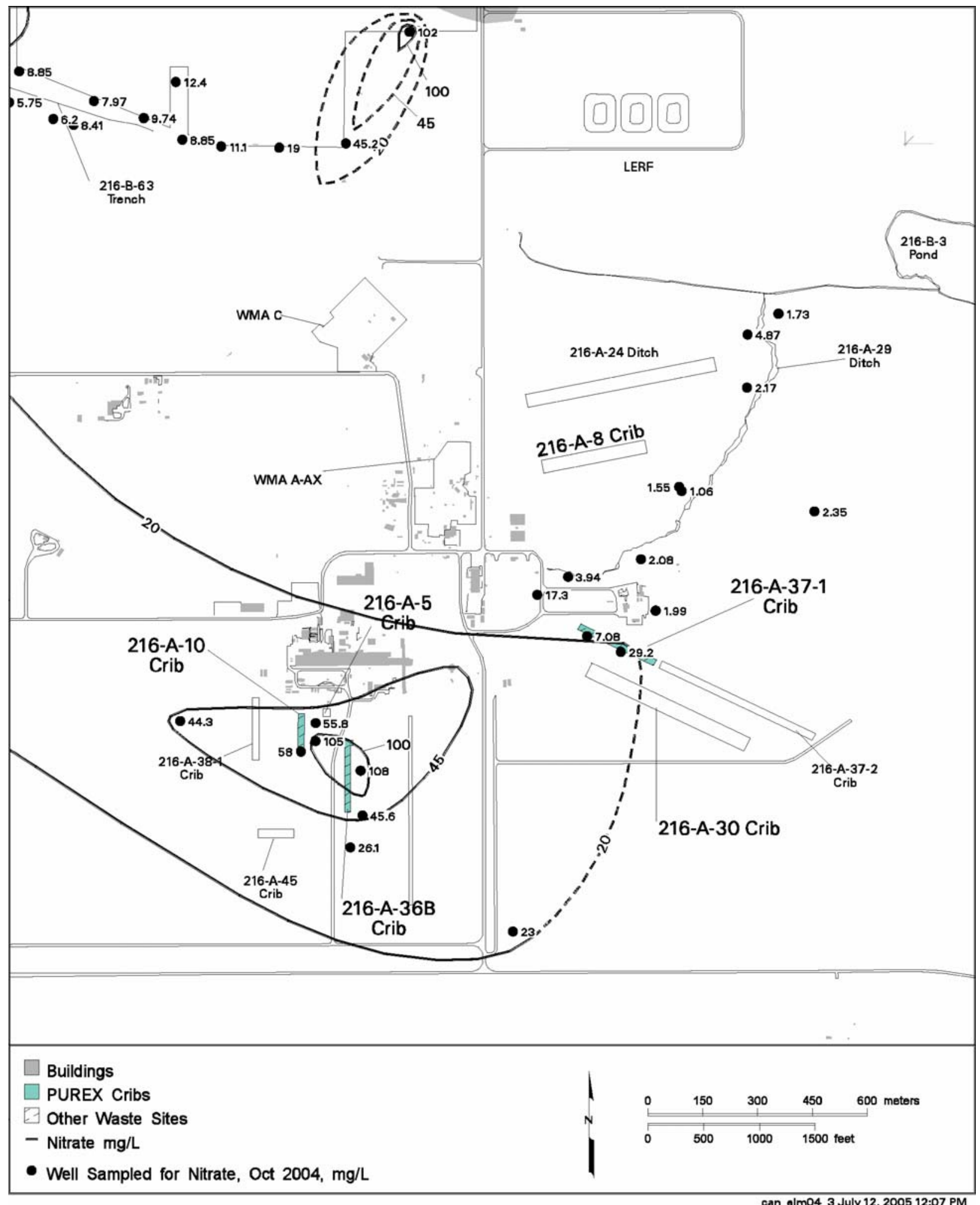

Figure 1.2. Nitrate Concentration in the Uppermost Aquifer, 200 East Area, October 2004 


\subsection{Conceptual Model}

A groundwater conceptual model is an evolving hypothesis that identifies the important features, events, and processes that control groundwater and contaminant movement. This model is based on results of previous geological and hydrogeological studies, sediment sampling, and groundwater monitoring. Primary references are Lindberg (1997), Williams et al. (2000), and groundwater monitoring annual reports (e.g., Hartman et al. 2005). The model provides a basis for designing the near-field well network.

The conceptual model for the 216-A-10, 216-A-36B, and 216-A-37-1 PUREX cribs includes the following elements:

- Liquid wastes released in the cribs migrated through the vadose zone into the groundwater.

- As the mobile constituents intercepted and mixed with groundwater in the unconfined aquifer, they moved laterally with the groundwater flow.

- A water-table mound was created by discharges to PUREX cribs and B-Pond, resulting in changes to the groundwater flow directions in the 200 East Area. More recently, groundwater flow has begun to revert toward the flow patterns that existed before the large discharges to B-Pond. Because of extremely low hydraulic gradient, flow direction (southeastward to eastward) was inferred from water-table elevations and plume migration. The water table in the 200 East Area has been declining since discharges to B-Pond were halted in 1997.

- Groundwater contamination tends to be higher in concentration near the water table, thus the nearfield wells are screened near the water table (Eddy et al. 1978).

- In the area around the PUREX cribs there are two hydrogeologic schemes represented by two vertical columns (Figure 2.1). Near the 216-A-10 and 216-A-36B cribs, groundwater in the uppermost unconfined aquifer, Hanford formation, is isolated from the groundwater in the confined Ringold aquifer by Unit 8 (Ringold lower mud unit). This hydrogeologic scheme incorporates two separate aquifers. Toward the northeast near the 216-A-37-1 crib, a large flood channel filled with Hanford formation sediment (deposited during cataclysmic Pleistocene floods) extends across the 200 East Area from northwest to the southeast. This flood channel extends through Unit 8, the Ringold Formation lower mud unit, a major locally confining layer, such that the sand and gravel of the Hanford formation lie directly upon the sand and gravel of the lower portions of the Ringold Formation (Unit 9). Therefore, within and near the large flood channel there is hydraulic communication between the unconfined Hanford aquifer and any partially or locally confined aquifers in the lower portions of the Ringold Formation. Thus, the northeastern hydrogeologic scheme, represented by the column to the right in Figure 2.1, has just one combined aquifer.

- Because the hydraulic conductivity of the channel fill is generally much higher than for Unit 9 (in the vicinity of the 216-A-37-1 crib), and there is an upward gradient in this region, groundwater from the confined Ringold aquifer system likely discharges into the highly transmissive channel-fill sediments where it mixes with groundwater of the unconfined Hanford aquifer. 


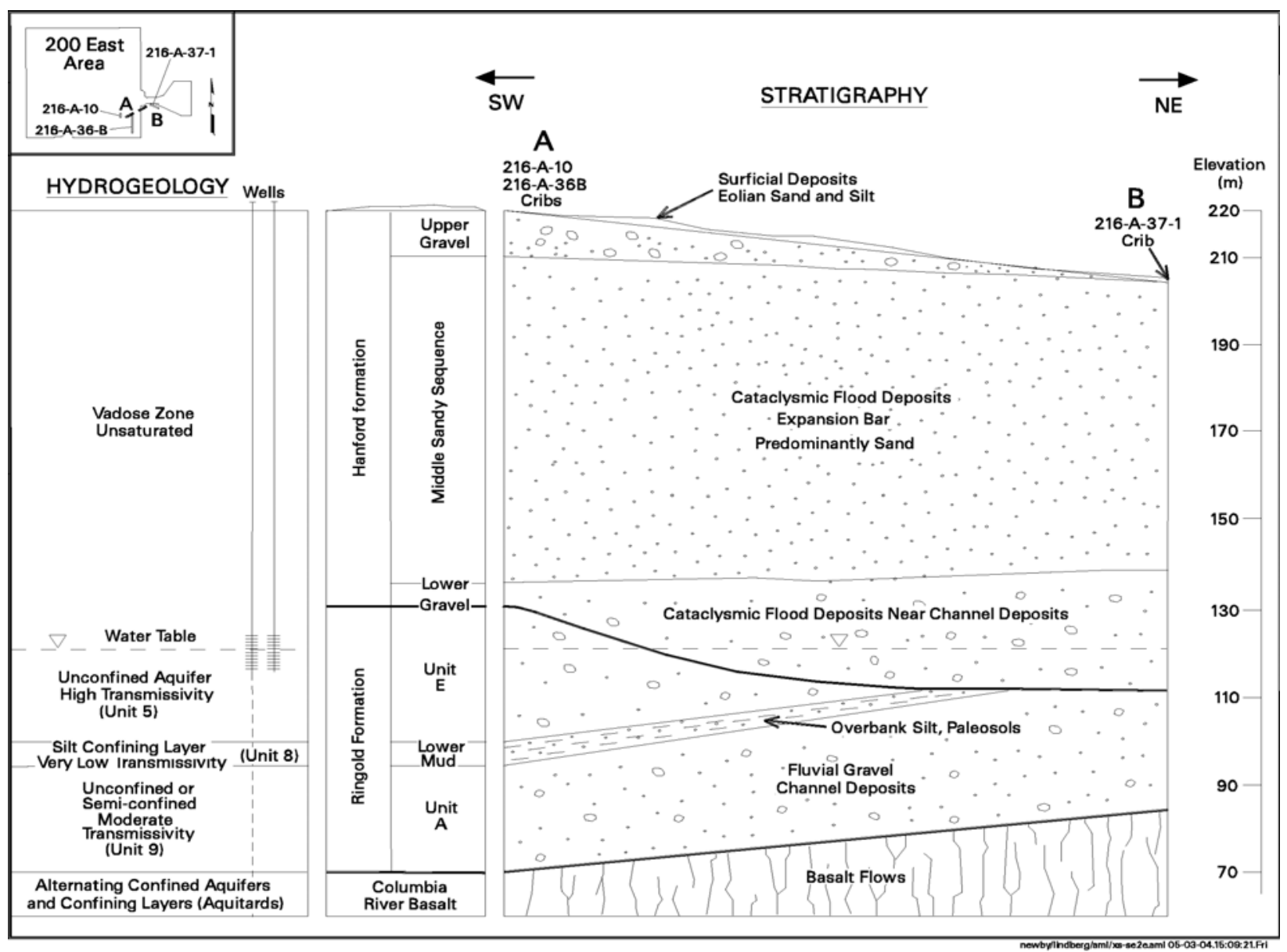

Figure 2.1. Hydrogeologic Conceptual Model Near PUREX Cribs, 200 East Area 


\subsection{Groundwater Monitoring Program}

This section describes the combined RCRA monitoring program for the 216-A-10, 216-A-36B, and 216-A-37-1 PUREX cribs. The objective of monitoring is to track plume extent and contaminant trends until final cleanup decisions are made. This monitoring plan will be modified, as necessary, to reflect the final record of decision for the 200-PO-1 Operable Unit.

\subsection{Monitoring Well Network}

The RCRA monitoring near-field network (Table 3.1) includes:

- Nine near-field downgradient wells, adjacent to the 216-A-10, 216-A-36B, or 216-A-37-1 cribs, to track concentration trends in the area of highest contamination.

- Two upgradient wells to provide information on quality of groundwater entering the area of the cribs.

- Far-field wells are monitored under the 200-PO-1 Operable Unit sampling and analysis plan (DOE/RL-2003-04).

All of the near-field wells monitor the top of the unconfined aquifer. As-built diagrams of the wells are included in the Appendix.

If a monitoring well becomes unsuitable for use, the well network will be re-evaluated to determine if the well will have to be deepened or replaced, whether the remaining wells are adequate to monitor the network, or whether another well, not currently being used, can be substituted. If a new well must be installed, it will be incorporated into the M-24 priority list.

\subsection{Constituent List and Sampling Frequency}

Nitrate is the primary constituent of interest. Additional constituents required by WAC 173-303400, and by reference, requirements in 40 CFR 265(d)(3) and (d)(4), include chloride, iron, manganese, phenols, sodium, and sulfate. Arsenic will no longer be monitored because it is not above background concentrations.

One representative well downgradient from each of the three RCRA PUREX cribs will be sampled quarterly. Data from these three wells will be assessed quarterly (required by 40 CFR 265.93 [d][7][i]) to determine if there are any changing contaminant conditions near the cribs. The other eight wells will be sampled semiannually (see Table 3.1). 
Table 3.1. Wells for RCRA Monitoring at the 216-A-10, 216-A-36B, and 216-A-37-1 PUREX Cribs

\begin{tabular}{|c|c|c|c|c|c|c|c|c|c|c|}
\hline \multirow[b]{2}{*}{ Well } & \multirow[b]{2}{*}{ Purpose; Comments } & \multirow[b]{2}{*}{ 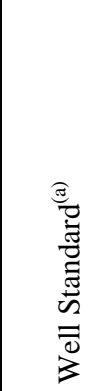 } & \multirow{2}{*}{$\begin{array}{c}\text { Pri- } \\
\text { mary } \\
\text { Consti } \\
\text {-tuent }\end{array}$} & \multicolumn{2}{|c|}{$\begin{array}{l}\text { Constituents } \\
\text { Supporting } \\
\text { Interpretation }\end{array}$} & \multicolumn{5}{|c|}{ Field Parameters } \\
\hline & & & & 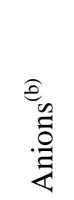 & 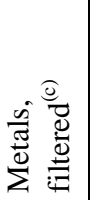 & $\stackrel{\mathbb{I}}{\mathrm{I}}$ & 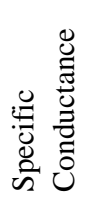 & 窇 & $\underset{:}{\stackrel{D}{0}}$ & 党 \\
\hline 299-E17-1 & Downgradient from A-10 Crib & PRE & $\mathrm{S}$ & $\mathrm{S}$ & S & $\mathrm{S}$ & S & $S$ & S & S \\
\hline 299-E17-14 & Downgradient from A-36B Crib & WAC & Q & $\mathrm{Q}$ & $\mathrm{Q}$ & $\mathrm{Q}$ & Q & $\mathrm{Q}$ & Q & Q \\
\hline 299-E17-16 & Downgradient from A-36B Crib & PRE & $\mathrm{S}$ & $\mathrm{S}$ & $\mathrm{S}$ & $\mathrm{S}$ & $\mathrm{S}$ & $\mathrm{S}$ & $\mathrm{S}$ & $\mathrm{S}$ \\
\hline 299-E17-18 & Downgradient from A-36B Crib & WAC & $\mathrm{S}$ & $\mathrm{S}$ & $\mathrm{S}$ & $\mathrm{S}$ & $\mathrm{S}$ & $\mathrm{S}$ & $\mathrm{S}$ & $\mathrm{S}$ \\
\hline 299-E17-19 & Downgradient from A-10 Crib & WAC & $\mathrm{S}$ & $\mathrm{S}$ & $\mathrm{S}$ & $\mathrm{S}$ & $S$ & $S$ & $\mathrm{~S}$ & $S$ \\
\hline 299-E24-16 & Downgradient from A-10 Crib & WAC & $\mathrm{Q}$ & $\mathrm{Q}$ & $\mathrm{Q}$ & $\mathrm{Q}$ & $\mathrm{Q}$ & $\mathrm{Q}$ & $\mathrm{Q}$ & $\mathrm{Q}$ \\
\hline 299-E24-18 & Upgradient from A-10 Crib & WAC & $\mathrm{S}$ & $\mathrm{S}$ & $\mathrm{S}$ & $\mathrm{S}$ & $\mathrm{S}$ & $\mathrm{S}$ & $\mathrm{S}$ & $\mathrm{S}$ \\
\hline 299-E25-17 & Downgradient from A-37-1 Crib & PRE & $\mathrm{S}$ & $\mathrm{S}$ & $\mathrm{S}$ & $\mathrm{S}$ & $S$ & $S$ & $\mathrm{~S}$ & $S$ \\
\hline 299-E25-19 & Downgradient from A-37-1 Crib & PRE & Q & Q & $\mathrm{Q}$ & $\mathrm{Q}$ & Q & Q & Q & Q \\
\hline 299-E25-31 & Upgradient from A-37-1 Crib & WAC & $\mathrm{S}$ & $\mathrm{S}$ & $\mathrm{S}$ & $\mathrm{S}$ & $\mathrm{S}$ & $\mathrm{S}$ & $\mathrm{S}$ & $\mathrm{S}$ \\
\hline $699-37-47 A$ & Downgradient from A-37-1 Crib & WAC & $S$ & S & $\mathrm{S}$ & S & S & S & $\mathrm{S}$ & S \\
\hline $\begin{array}{c}\text { PRE = Well } \\
\text { WAC = We } \\
\text { Anions anal } \\
\text { Metals analy } \\
\text { samples. } \\
=\text { semiannually } \\
=\text { quarterly }\end{array}$ & $\begin{array}{l}\text { not constructed to Washington Adr } \\
\text { l constructed to Washington Admi } \\
\text { sis includes at a minimum chlorid } \\
\text { sis includes at a minimum iron, m }\end{array}$ & $\begin{array}{l}\text { Inistrativ } \\
\text { strative } \\
\text { and sulfa } \\
\text { iganese, }\end{array}$ & $\begin{array}{l}\text { Code ( } \\
\text { ode (W }\end{array}$ & $\begin{array}{l}\text { WAC } \\
\text { AC } 17 \\
\text { um. A }\end{array}$ & $\begin{array}{l}3-16 \\
160)\end{array}$ & & un on & ered & & \\
\hline
\end{tabular}

\subsection{Water Level Monitoring}

Field personnel measure depth to water before sampling, or at other times as specified by the Groundwater Performance Assessment Project (groundwater project) (e.g., annual water-level measurements). The tapes used to make depth measurements are calibrated semiannually. Field personnel obtain two consecutive measurements that agree within $6 \mathrm{~mm}(0.02 \mathrm{ft})$ and record them along with date, time, measuring tape number, and other pertinent information. Depth to water is subtracted from the elevation of a reference point (usually top of casing) to obtain water-level elevation. Water-level elevations are used to construct water-table maps of the 200 East Area.

Groundwater flow direction beneath the 216-A-10, 216-A-36B, and 216-A-37-1 PUREX cribs is inferred from the water-table map(s) and plume maps. Rate of flow is estimated from hydraulic gradient, hydraulic conductivity, and porosity or from rates of contaminant movement.

\subsection{Sampling and Analysis Protocol}

RCRA groundwater monitoring for the 216-A-10, 216-A-36B, and 216-A-37-1 PUREX cribs is part of Hanford's groundwater project and follows project quality assurance (QA) protocols. Groundwater 
monitoring for these units will follow the requirements of the most recent revision of the QA project plan. This monitoring plan need not be revised to cite future revisions of those protocols.

Project staff schedule sampling and initiate paperwork and oversee sample collection, shipping, and analysis. Quality requirements for any work subcontracted are specified in statements of work or contracts.

The statement of work for sampling activities specifies that those activities will be conducted in accordance with a QA project plan that meets the requirements defined in Requirements for Quality Assurance Project Plans, EPA/240/B-01/003 (EPA 2001). Additional requirements are specified in the statement of work.

Groundwater project staff conduct laboratory audits and field surveillances to assess the quality of subcontracted work and initiate corrective action if needed.

\subsubsection{Scheduling Groundwater Sampling}

The groundwater project schedules well sampling. Many Hanford Site wells are sampled for multiple objectives and requirements; e.g., RCRA, CERCLA, and AEA. Scheduling activities help manage the overlap, eliminating redundant sampling and meeting the needs of each sampling objective. Scheduling activities include the following:

- Each fiscal year, project scientists provide well lists, constituent lists, and sampling frequency. Each month, project scientists review the sampling schedule for the following month. Changes are requested via Sampling and Analysis Schedule Change Request Forms and approved by the Sampling and Analysis Task Leader, and Monitoring Project Manager.

- Project staff track sampling and analysis through an electronic schedule database stored on a server at Pacific Northwest National Laboratory (PNNL). Quality control samples also are managed through this database. A scheduling program generates unique sample numbers, and a special user interface generates sample authorization forms, field services reports, groundwater sample reports, chain-of-custody forms, and sample container labels.

- Sampling and analysis staff verify that well name, sample numbers, bottle sizes, preservatives, etc. are indicated properly on the paperwork, which is transmitted to the sample collector. Staff verify that the paperwork was generated correctly.

- At each month's end, project staff use the schedule database to determine if any wells were not sampled as scheduled. If the wells or sampling pumps require maintenance, sampling is rescheduled following repair. If a well can no longer be sampled it is cancelled, and the reason is recorded in the database. DOE will notify the Washington State Department of Ecology (Ecology) if sampling is delayed past the end of the scheduled quarter or if a well cannot be sampled (see Sections 3.1 and 5.4). 


\subsubsection{Chain of Custody}

The sample collector uses chain-of-custody forms to document the possession of collecting groundwater samples from the time of collection through data reporting. The physical integrity of the samples is maintained by samples being in custody of the sample collector. The forms are generated during scheduling (see Section 3.4.1) and managed by the sample collector. Samplers enter required information on the forms, including the following:

- Sampler's name(s)

- Collection date and time.

In addition, the following are placed on the chain-of-custody forms:

- Method of shipment and destination

- Sample identification numbers

- Analysis methods

- Preservation methods.

When samples are transferred from one custodian to another (e.g., from sampler to shipper or shipper to analytical laboratory), the receiving custodian inspects the form and samples and notes any deficiencies. Each transfer of custody is documented by the printed names and signatures of the custodian relinquishing the samples and the custodian receiving the samples, and the time and date of transfer.

\subsubsection{Sample Collection}

All of the wells in the 216-A-10, 216-A-36B, and 216-A-37-1 PUREX cribs network are equipped with dedicated sampling pumps. Field personnel measure water levels in each well prior to sampling (see Section 3.3), then purge stagnant water from the well. Groundwater samples generally are collected after three casing volumes of water have been purged from the well or after field parameters ( $\mathrm{pH}$, temperature, specific conductance, and turbidity) have stabilized.

For routine groundwater samples, preservatives are added to the collection bottles, if necessary, before their use in the field. Samples for metals analyses are filtered in the field with 0.45 - $\mu \mathrm{m}$, in-line, disposable filters. After sampling, $\mathrm{pH}$, temperature, and specific conductance are measured again. Sample bottles are sealed with evidence tape and placed in a cooler with ice for shipping.

The samplers record the date, time, personnel, field measurements, and other pertinent information in the comment section on the Groundwater Service Report and in the field logbook and complete the chain of custody form as described in Section 3.4.2.

\subsubsection{Analytical Protocols}

Instruments for field measurements (e.g., $\mathrm{pH}$, specific conductance, temperature, and turbidity) are calibrated using standard solutions prior to use and are operated according to manufacturer's instructions and/or samplers' operating procedures. Each instrument is assigned a unique number that is tracked on field documentation calibration report and calibrated and controlled. 
Laboratory analytical methods are specified in contracts with the laboratories and are standard methods from Test Methods for Evaluating Solid Wastes, Physical/Chemical Methods (EPA 1986, as amended) or Methods for Chemical Analysis of Water and Wastes (EPA 1983). 


\subsection{Quality Assurance}

The groundwater project's QA protocols meet EPA Requirements for Quality Assurance Project Plans, EPA/240/B-01/003 (EPA 2001). Also, the project QA program is based on QA requirements of DOE Order 414.1A, Quality Assurance, and 10 CFR 830, Subpart A - General Provisions/Quality Assurance Requirements as delineated in the PNNL Standard Based Management System. Quality control requirements are included in the groundwater project QA plan, and quality control sampling requirements for subcontracted work are discussed in the statement of work with the subcontractor.

The groundwater project's quality control program is designed to assess and enhance the reliability and validity of groundwater data. This is accomplished through evaluating the results of quality control samples, conducting audits, and validating groundwater data. This section describes the quality control program for the entire groundwater project, which includes PUREX cribs. The quality control elements necessary for the groundwater project are based on EPA guidance cited in the Tri-Party Agreement Action Plan, Section 6.5 (Ecology et al. 1998). Accuracy, precision, and detection are the primary parameters used to assess data quality (Mitchell et al. 1985). Data for these parameters are obtained from two categories of quality control samples: those that provide checks on field and laboratory activities (field quality control) and those that monitor laboratory performance (laboratory quality control). Table 4.1 summarizes the types of samples in each category and the sample frequencies and characteristics evaluated.

Table 4.1. Quality Control Samples

\begin{tabular}{|c|c|c|}
\hline Sample Type & Primary Characteristics Evaluated & Frequency \\
\hline \multicolumn{3}{|l|}{ Field Quality Control } \\
\hline Full Trip Blank & Contamination from containers or transportation & 1 per 20 well trips \\
\hline Field Transfer Blank & Airborne contamination from the sampling site & $\begin{array}{l}1 \text { each day volatile organic } \\
\text { compound samples are collected }\end{array}$ \\
\hline Equipment Blank ${ }^{(a)}$ & $\begin{array}{l}\text { Contamination from nondedicated sampling } \\
\text { equipment }\end{array}$ & 1 per 10 well trips or as needed ${ }^{(b)}$ \\
\hline Duplicate Samples & Reproducibility & 1 per 20 well trips \\
\hline \multicolumn{3}{|c|}{ Laboratory Quality Control } \\
\hline Method Blank & Laboratory contamination & 1 per batch \\
\hline Lab Duplicates & Laboratory reproducibility & Method/contract specific ${ }^{(c)}$ \\
\hline Matrix Spike & Matrix effects and laboratory accuracy & Method/contract specific ${ }^{(c)}$ \\
\hline Matrix Spike Duplicate & Laboratory reproducibility and accuracy & Method/contract specific ${ }^{(c)}$ \\
\hline Surrogates & Recovery/yield & Method/contract specific ${ }^{(c)}$ \\
\hline Laboratory Control Sample & Accuracy & 1 per batch \\
\hline Double Blind Standards & Accuracy and precision & Varies by constituent ${ }^{(\mathrm{d})}$ \\
\hline \multicolumn{3}{|c|}{ (a) Not applicable for PUREX cribs - dedicated sampling equipment used. } \\
\hline \multicolumn{3}{|c|}{$\begin{array}{l}\text { (b) When a new type of non-dedicated sampling equipment is used, an equipment blank should be collected } \\
\text { every time sampling occurs until it can be shown that less frequent collection of equipment blanks is adequate } \\
\text { to monitor the equipment's decontamination procedure. }\end{array}$} \\
\hline \multicolumn{3}{|c|}{$\begin{array}{l}\text { (c) If called for by the analytical method, duplicates, matrix spikes, and matrix spike duplicates are typically } \\
\text { analyzed at a frequency of } 1 \text { per } 20 \text { samples. Surrogates are routinely included in every sample for most gas }\end{array}$} \\
\hline \multicolumn{3}{|l|}{ (d) $\begin{array}{l}\mathrm{D} \\
\operatorname{tri}\end{array}$} \\
\hline
\end{tabular}




\subsection{Quality Control Criteria}

Quality control data are evaluated based on established acceptance criteria for each quality control sample type. For field and method blanks, the acceptance limit is generally two times the instrument detection limit (metals), or method detection limit (other chemical parameters). However, for common laboratory contaminants such as acetone, methylene chloride, 2-butanone, and phthalate esters, the limit is five times the method detection limit. Groundwater samples that are associated (i.e., collected on the same date and analyzed by the same method) with out-of-limit field blanks are flagged with a "Q" in the database to indicate a potential contamination problem.

Field duplicates must agree within $20 \%$, as measured by the relative percent difference (RPD), to be acceptable. Only those field duplicates with at least one result greater than five times the appropriate detection limit are evaluated. Unacceptable field duplicate results are also flagged with a "Q" in the database.

The acceptance criteria for laboratory duplicates, matrix spikes, matrix spike duplicates, surrogates, and laboratory control samples are generally derived from historical data at the laboratories in accordance with Test Methods for Evaluating Solid Wastes, Physical/Chemical Methods (EPA 1986, as amended). Typical acceptance limits are within $25 \%$ of the expected values, although the limits may vary considerably with the method and analyte.

Table 4.2 lists the acceptable recovery limits for the double blind standards. These samples are prepared by spiking background well water (currently wells 699-19-88 and 699-49-100C) with known concentrations of constituents of interest. Spiking concentrations range from the detection limit to the upper limit of concentration determined in groundwater on the Hanford Site. Double blind standard results that are outside the acceptance limits are investigated, and appropriate actions are taken if necessary.

Table 4.2. Recovery Limits for Double Blind Standards

\begin{tabular}{|l|c|c|l|}
\hline Constituent & Frequency & Recovery Limits & Precision Limits (RSD) \\
\hline Specific conductance & Quarterly & $75-125 \%$ & $25 \%$ \\
\hline Total organic carbon ${ }^{(a)}$ & Quarterly & $75-125 \%$ & Varies with spiking compound \\
\hline Total organic halides ${ }^{(b)}$ & Quarterly & $75-125 \%$ & Varies with spiking compound \\
\hline Cyanide & Quarterly & $75-125 \%$ & $25 \%$ \\
\hline Fluoride & Quarterly & $75-125 \%$ & $25 \%$ \\
\hline Nitrate & Quarterly & $75-125 \%$ & $25 \%$ \\
\hline Chromium & Annually & $80-120 \%$ & $20 \%$ \\
\hline Carbon tetrachloride & Quarterly & $75-125 \%$ & $25 \%$ \\
\hline Chloroform & Quarterly & $75-125 \%$ & $25 \%$ \\
\hline Trichloroethene & Quarterly & $75-125 \%$ & $25 \%$ \\
\hline \multicolumn{3}{|c|}{ (a) The spiking compound generally used for total organic carbon is potassium hydrogen phthalate. } \\
Other spiking compounds may also be used. \\
(b) Two sets of spikes for total organic halides will be used. The first should be prepared with 2,4,5- \\
trichlorophenol. The second set will be spiked with a mixture of carbon tetrachloride, chloroform, \\
and trichloroethene. \\
RSD = Relative Standard Deviation \\
\hline
\end{tabular}


Holding time is the elapsed time period between sample collection and analysis. Exceeding recommended holding times could result in changes in constituent concentrations due to volatilization, decomposition, or other chemical alterations. Recommended holding times depend on the analytical method, as specified in Test Methods for Evaluating Solid Wastes, Physical/Chemical Methods (EPA 1986, as amended) or Methods for Chemical Analysis of Water and Wastes (EPA 1983). These holding times are specified in laboratory contracts. Data associated with exceeded holding times are flagged with an " $\mathrm{H}$ " in the Hanford Environmental Information System (HEIS) database. Flagged data generally are suitable for use in plume maps and trend plots, but may not be suitable for decision-making.

Additional quality control measures include laboratory audits and participation in nationally based performance evaluation studies. The contract laboratories participate in national studies such as the EPAsanctioned Water Pollution and Water Supply Performance Evaluation studies. The groundwater project periodically audits the analytical laboratories to identify and solve quality problems, or to prevent such problems. Audit results are used to improve performance. Summaries of audit results and performance evaluation studies are presented in the annual groundwater monitoring report.

\subsection{Groundwater Data Validation Process}

The groundwater project's data validation process provides requirements and guidance for validation of groundwater data that are routinely collected as part of the groundwater project. Validation is a systematic process of reviewing data against a set of criteria to determine whether the data are acceptable for their intended use. This process applies to groundwater data that have been verified (see Section 5.1) and loaded into HEIS. The outcome of the activities described below is an electronic data set with suspect or erroneous data corrected or flagged. Groundwater project staff document the validation process quarterly. Documentation is stored in the project file.

Responsibilities for data validation are divided among project staff. Each RCRA unit or geographic region is assigned to a project scientist, who is familiar with the hydrogeologic conditions of that site. The data validation process includes the following elements.

- Generation of data reports: Twice each month (initial data review), data management staff provide tables of newly loaded data to project scientists for evaluation (biweekly reports). Also, after laboratory results from a reporting quarter have been loaded into HEIS, staff produce tables of waterlevel data and analytical data for wells sampled within that quarter (quarterly reports, formal review). The quarterly data reports include any data flags added during the quality control evaluation or as a result of prior data review.

- Project scientist evaluation: As soon as practical after receiving biweekly reports, project scientists review the data to identify changes in groundwater results or potential data errors. Evaluation techniques include comparing key constituents to historical trends or spatial patterns. Other data checks may include comparison of general parameters to their specific counterparts (e.g., conductivity to ions) and calculation of charge balances. Project scientists request data reviews (Request for Data Review) if appropriate (see Section 5.2). If necessary, the laboratory may be asked to check calculations or reanalyze the sample, or the well may be resampled. After receiving quarterly reports, project scientists review sampling summary tables to determine whether network wells were sampled and analyzed as scheduled. If not, they work with other project staff to resolve the problem. Project scientists also review quarterly reports of analytical and water-level data using 
the same techniques as for biweekly reports. Unlike the biweekly reports, the quarterly reports usually include a full data set (i.e., all the data from the wells sampled during the previous quarter have been received and loaded into HEIS).

- Staff report results of quality control evaluations informally to project staff, DOE, and Ecology each quarter. If significant changes occur in groundwater chemistry results, these results are reported to DOE as necessary. Results for each fiscal year are described in the annual groundwater monitoring report. 


\subsection{Data Management and Reporting}

This section describes how groundwater data are stored, retrieved, and interpreted.

\subsection{Loading and Verifying Data}

The contract laboratories report analytical results electronically and in hard copy. The electronic results are loaded into HEIS after the identified errors have been resolved and the results re-reported. Hard copy data reports and field records are maintained as part of the project records unit-specific file for the treatment, storage, and disposal unit. Project staff perform an array of computer checks on the electronic file from the laboratories for formatting, allowed values, data flagging (qualifiers), and completeness. Verification of the hard copy results includes checks for 1) completeness, 2) notes on condition of samples upon receipt by the laboratory, 3) notes on problems that arose during the analysis of the samples, and 4) correct reporting of results. If data are incomplete or deficient, staff work with the laboratory to get the problems corrected. Notes on condition of samples or problems during analysis may be used to support data reviews (see Section 5.2).

Field data such as specific conductance, $\mathrm{pH}$, temperature, turbidity, and depth-to-water are recorded on field records. Data management staff enter these results into HEIS manually through data-entry screens, verify each value against the hard copy, and initial each value on the hard copy.

\subsection{Data Review}

The groundwater project conducts special reviews of groundwater analytical data or field measurements when results are in question. Groundwater project staff document the process on a review form, and results are used to flag the data appropriately in HEIS. Various staff may initiate a review form: e.g., project scientists, data management staff, and quality control staff. The data review process includes the following steps:

- The initiator fills out required information on the review form, such as sample number, constituent, and reason for the request (e.g., "result is two orders of magnitude greater than historical results and disagrees with duplicate”). The initiator recommends an action, such as a data re-check, sample re-analysis, well re-sampling, or simply flagging the data as suspect in HEIS.

- The data review coordinator determines that the review form does not duplicate a previously submitted review form, then assigns a unique review form number and records it on the form. A temporary flag is assigned to the data in HEIS indicating the data are undergoing review ("F" flag).

- If laboratory action is required, the data review coordinator records the laboratory's response on the review form. Other documentation also may be relevant, such as chain-of-custody forms, field records, calibration logs, or chemist's sheets.

- A project scientist assigned to examine a review form determines and records the appropriate response and action on the review form including changes to be made to the data flags in HEIS. Actions may include updating HEIS with corrected data or result of re-analysis, flagging existing 
data (e.g., "R” for reject, "Y” for suspect, “G” for good), and/or adding comments. Data management staff updates the temporary "F" flag to the final flag in HEIS.

- The data review coordinator signs the review form to indicate its closure.

- If a review form is filed on data that are not “owned" by the groundwater project, the data review coordinator forwards a copy of the partially filled review form to the appropriate contact for their action. The review is then closed.

\subsection{Interpretation}

After data are validated and verified, the acceptable data are used to interpret groundwater conditions at the site. Interpretive techniques include:

- Hydrographs - graph water levels vs. time to determine decreases, increases, seasonal, or manmade fluctuations in groundwater levels.

- Water-table maps - use water-table elevations from multiple wells to construct contour maps to estimate flow directions. Groundwater flow is assumed to be perpendicular to lines of equal potential.

- Trend plots - graph concentrations of constituents vs. time to determine increases, decreases, and fluctuations. May be used in tandem with hydrographs and/or water-table maps to determine if concentrations relate to changes in water level or in groundwater flow directions.

- Plume maps - map distributions of chemical or radiological constituents in the aquifer to determine extent of contamination. Changes in plume distribution over time aid in determining movement of plumes and direction of flow.

- Contaminant ratios - can sometimes be used to distinguish between different sources of contamination.

\subsection{Reporting}

Results of PUREX assessment monitoring are reported annually in groundwater monitoring reports (e.g., Hartman et al. 2005). DOE also will continue to provide informal quarterly reports to Ecology with updates to PUEX assessment monitoring. The quarterly reports also inform Ecology if sampling is delayed past the end of the scheduled quarter. Chemistry and water-level data are reviewed after each sampling event and are available in HEIS. When needed, DOE will report specific incidents affecting RCRA PUREX cribs groundwater monitoring (e.g., unsuitable wells, delayed sampling) as described in Sections 3.1 and 3.4.1. 


\subsection{References}

10 CFR 830. Energy Nuclear Safety Management, Subpart A - Quality Assurance Requirements, U.S. Code of Federal Regulations.

40 CFR 265(d)(3) and (d)(4). 2004. Interim Status Standards for Owners and Operators of Hazardous Waste Treatment, Storage, and Disposal Facilities. U.S. Code of Federal Regulations.

DOE Order 414.1A. 1999. Quality Assurance, U.S. Department of Energy, Washington, D.C.

Aldrich, RC. 1987. Radioactive Liquid Wastes Discharged to Ground in the 200 Areas During 1986, RHO-HQ-SR-86-3, 4QLIQP, Rockwell Hanford Company, Richland, Washington.

Atomic Energy Act (AEA). 1954. As amended, Ch. 1073, 68 Stat. 919, 42 USC 2011 et seq.

Chou, CJ. 1991. Statistical Approach on RCRA Groundwater Monitoring Projects at the Hanford Site, WHC-SA-1124-FP, Westinghouse Hanford Company, Richland, Washington.

Comprehensive Environmental Response, Compensation, and Liability Act (CERCLA). 1980. Public Law 96-150, as amended, 94 Stat. 2767, 42 USC 9601 et seq.

Eddy, PA, DA Myers, and JR Raymond. 1978. Vertical Contamination in the Unconfined Groundwater at the Hanford Site, Washington. PNL-2724, Pacific Northwest Laboratory, Richland, Washington.

Hartman MJ, LF Morasch, and WD Webber (eds.). 2005. Hanford Site Groundwater Monitoring for Fiscal Year 2004. PNNL-15070, Pacific Northwest National Laboratory, Richland, Washington.

Kasza, GL. 1992. Borehole Completion Data Package for 216-A-10 and 216-A-36B Cribs, WHC-SD-EN-AP-170, Westinghouse Hanford Company, Richland, Washington.

Lindberg, JW. 1997. Combination RCRA Groundwater Monitoring Plan for the 216-A-10, 216-A-36b, and 216-3-37-1 PUREX Cribs. PNNL-11523 Rev.0, Pacific Northwest National Laboratory, Richland, Washington.

Mitchell WJ, RC Rhodes, and FF McElroy. 1985. "Determination of Measurement Data Quality and Establishment of Achievable Goals for Environmental Measurements.” Quality Assurance for Environmental Measurements, ASTM STP 867.

Resource Conservation and Recovery Act (RCRA). 1976. Public Law 94-580, as amended, , 42 USC 6901 et seq.

U.S. Department of Energy-Richland Operations Office (DOE-RL). 1991. Annual Report for RCRA Groundwater Monitoring Projects at Hanford Site Facilities for 1990, DOE/RL-91-03, U.S. Department of Energy, Richland Field Office, Richland, Washington. 
U.S. Department of Energy-Richland Operations Office (DOE-RL). 1997. Hanford Site Background: Part3, Groundwater Background. DOE/RL-96-61, U.S. Department of Energy, Richland Operations Office, Richland, Washington.

U.S. Department of Energy-Richland Operations Office (DOE-RL). 1998. Hanford Analytical Services Quality Assurance Requirements Documents, DOE-RL-96-98, HASQARD, Volumes 1, 2, 3, and 4. U.S. Department of Energy, Richland Operations Office, Richland, Washington.

U.S. Department of Energy-Richland Operations Office (DOE-RL). 2003. Sampling and Analysis Plan for the 200-PO-1 Groundwater Operable Unit. DOE/RL-2003-04, Rev. 0, U.S. Department of Energy, Richland, Washington.

U.S. Environmental Protection Agency (EPA). 1986, as amended. Test Methods for Evaluating Solid Waste: Physical/Chemical Methods. SW-846, Third Edition, Office of Solid Waste and Emergency Response, U.S Environmental Protection Agency, Washington, D.C.

U.S. Environmental Protection Agency (EPA). 1983. Methods for Chemical Analysis of Water and Wastes. EPA-600/4-79-020, U.S Environmental Protection Agency, Washington, D.C.

U.S. Environmental Protection Agency (EPA). 2001. EPA Requirements for Quality Assurance Project Plans. EPA/240/B-01/003 (QA/R-5) March 2001 as revised. U.S. Environmental Protection Agency, Washington, D.C.

Washington Administrative Code (WAC). "Minimum Standards for Construction and Maintenance of Wells.” WAC 173-160, Washington Administrative Code, Olympia, Washington.

Washington State Department of Ecology (Ecology), U.S. Environmental Protection Agency, and U.S. Department of Energy. 1998, as amended. Hanford Federal Facility Agreement and Consent Order. document No. 89-10, Rev. 5 (The Tri-Party Agreement), Olympia, Washington.

WHC-SD-EN-TI-020. 1993. Groundwater Field Characterization Report for the 200 Aggregate Area Management Study, Westinghouse Hanford Company, Richland, Washington.

Williams BA, BN Bjornstad, R Schalla, and WD Webber. 2000. Revised Hydrogeology for the Suprabasalt Aquifer System, 200-East Area and Vicinity, Hanford Site, Washington. PNNL-12261, Pacific Northwest National Laboratory, Richland, Washington. 
Appendix

As-Built Diagrams of Monitoring Wells 


\section{Appendix}

\section{As-Built Diagrams of Monitoring Wells}

This appendix contains diagrams of wells in the near-field PUREX Cribs groundwater monitoring network. The diagrams summarize stratigraphy and well construction materials. The diagrams are presented in numerical order.

\begin{tabular}{cl}
\hline \multicolumn{2}{c}{$\begin{array}{c}\text { Monitoring Wells for near-field PUREX Cribs } \\
\text { groundwater monitoring network. }\end{array}$} \\
\hline \multicolumn{1}{c}{ Well } & \multicolumn{1}{c}{ Purpose; comments } \\
\hline 299-E17-1 & Downgradient from A-10 Crib \\
299-E17-14 & Downgradient from A-36B Crib \\
$299-E 17-16$ & Downgradient from A-36B Crib \\
299-E17-18 & Downgradient from A-36B Crib \\
299-E17-19 & Downgradient from A-10 Crib \\
299-E24-16 & Downgradient from A-10 Crib \\
299-E24-18 & Upgradient from A-10 Crib \\
299-E25-17 & Downgradient from A-37-1 Crib \\
299-E25-19 & Downgradient from A-37-1 Crib \\
299-E25-31 & Upgradient from A-37-1 Crib \\
699-37-47A & Downgradient from A-37-1 Crib
\end{tabular}




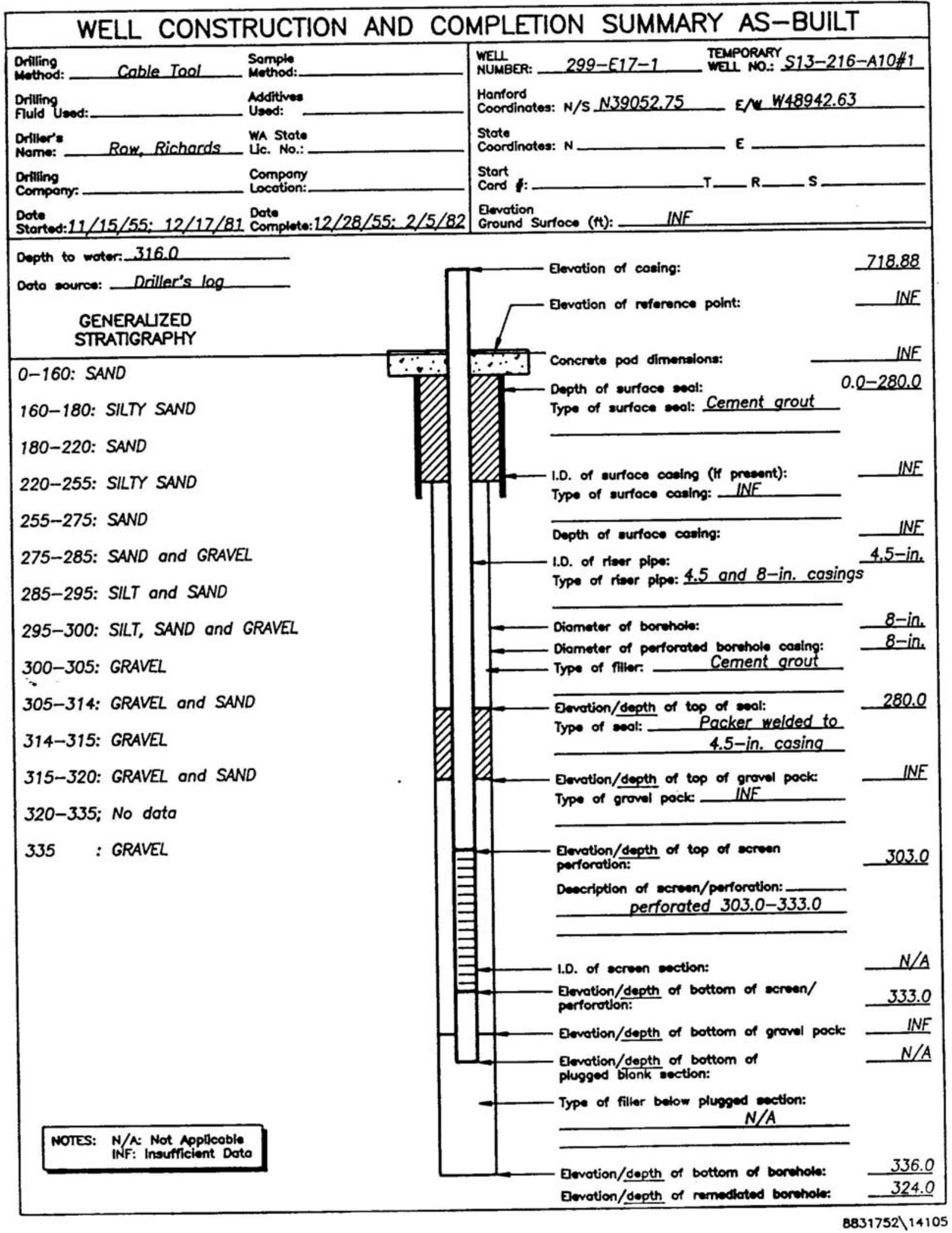

Figure A.1. Well 299-E17-1 Downgradient from A-10 Crib 


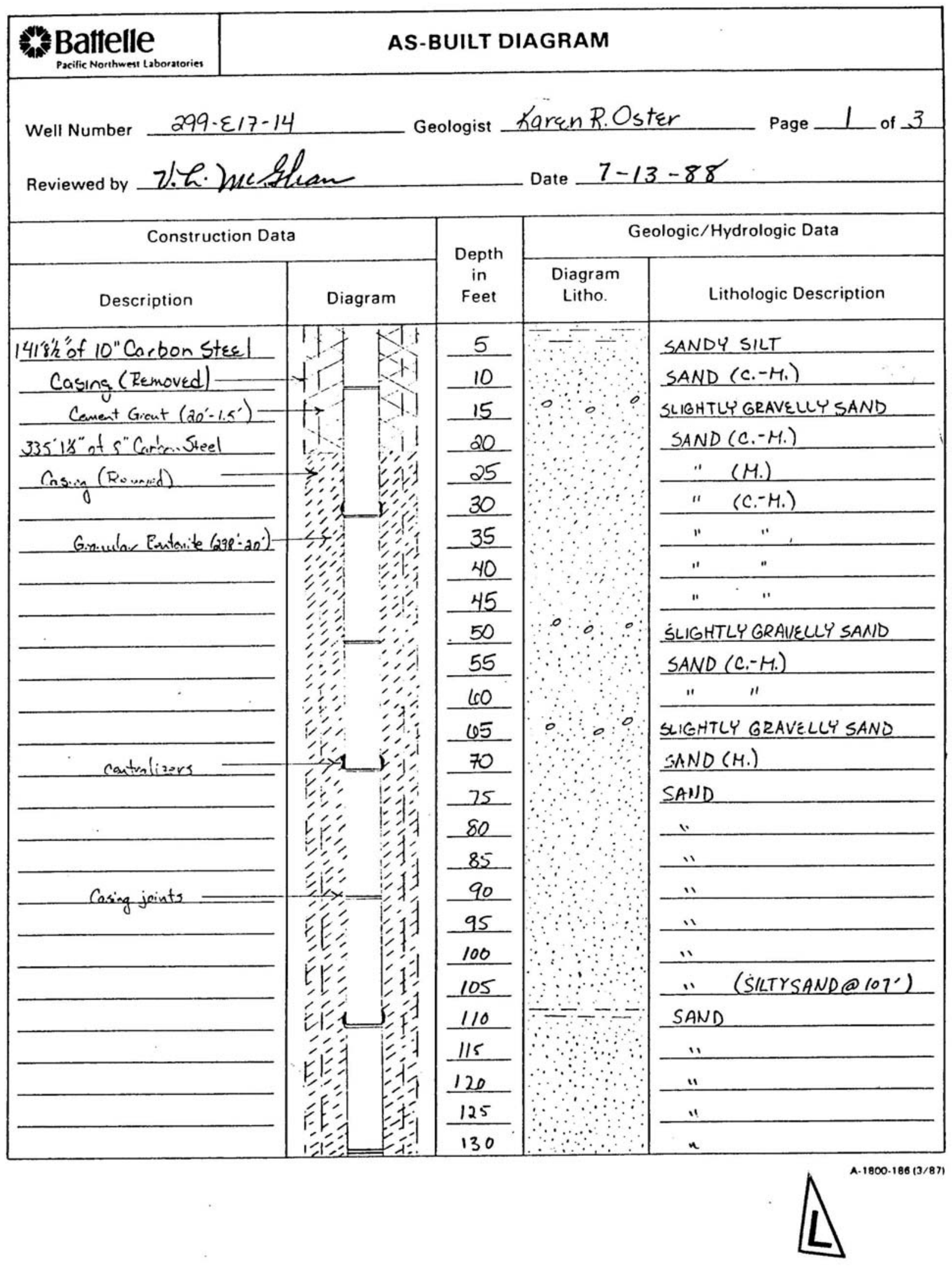

Figure A.2. Well 299-E17-14 Downgradient from A-36B Crib 


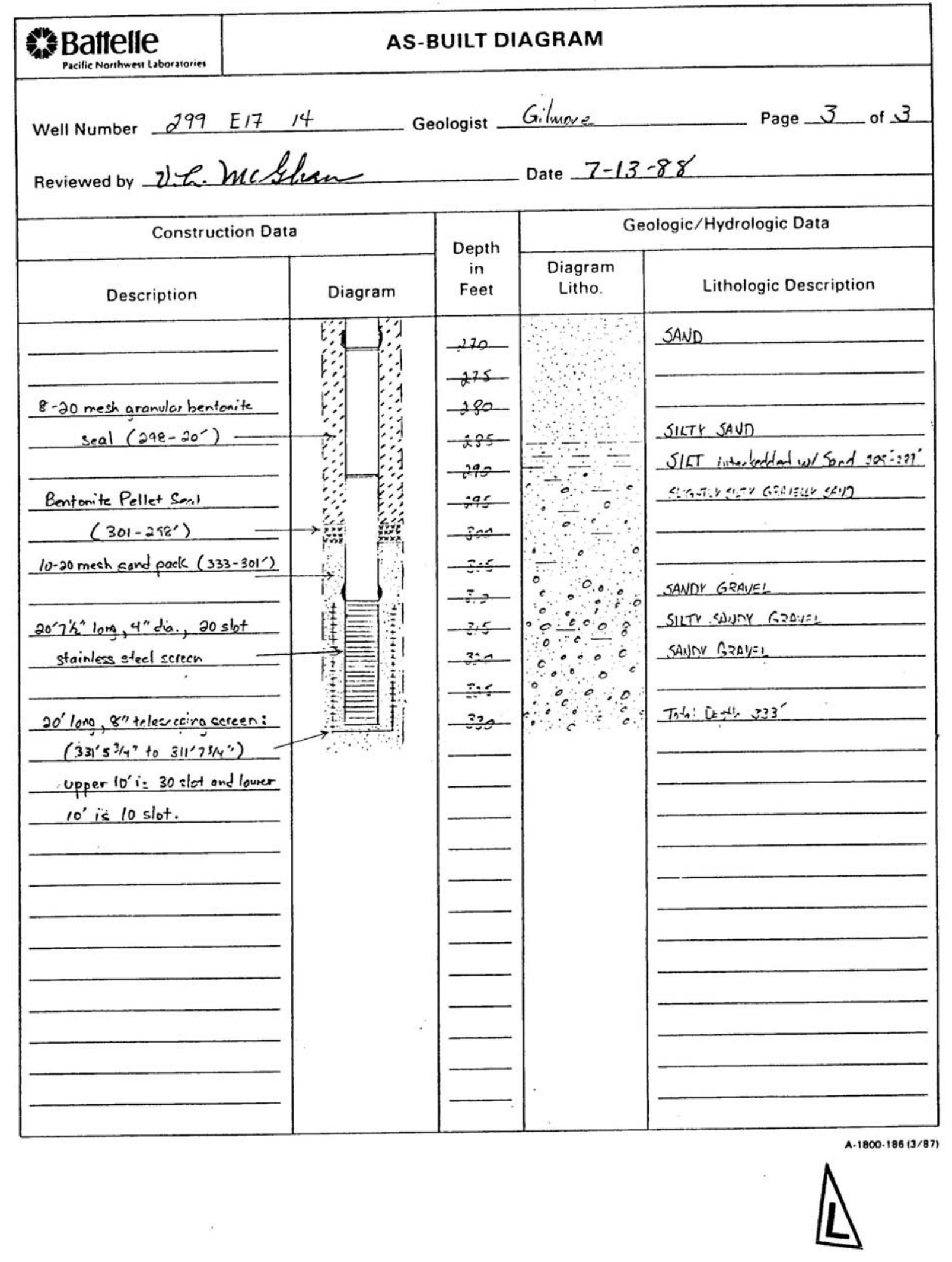

Figure A.2. (contd) 


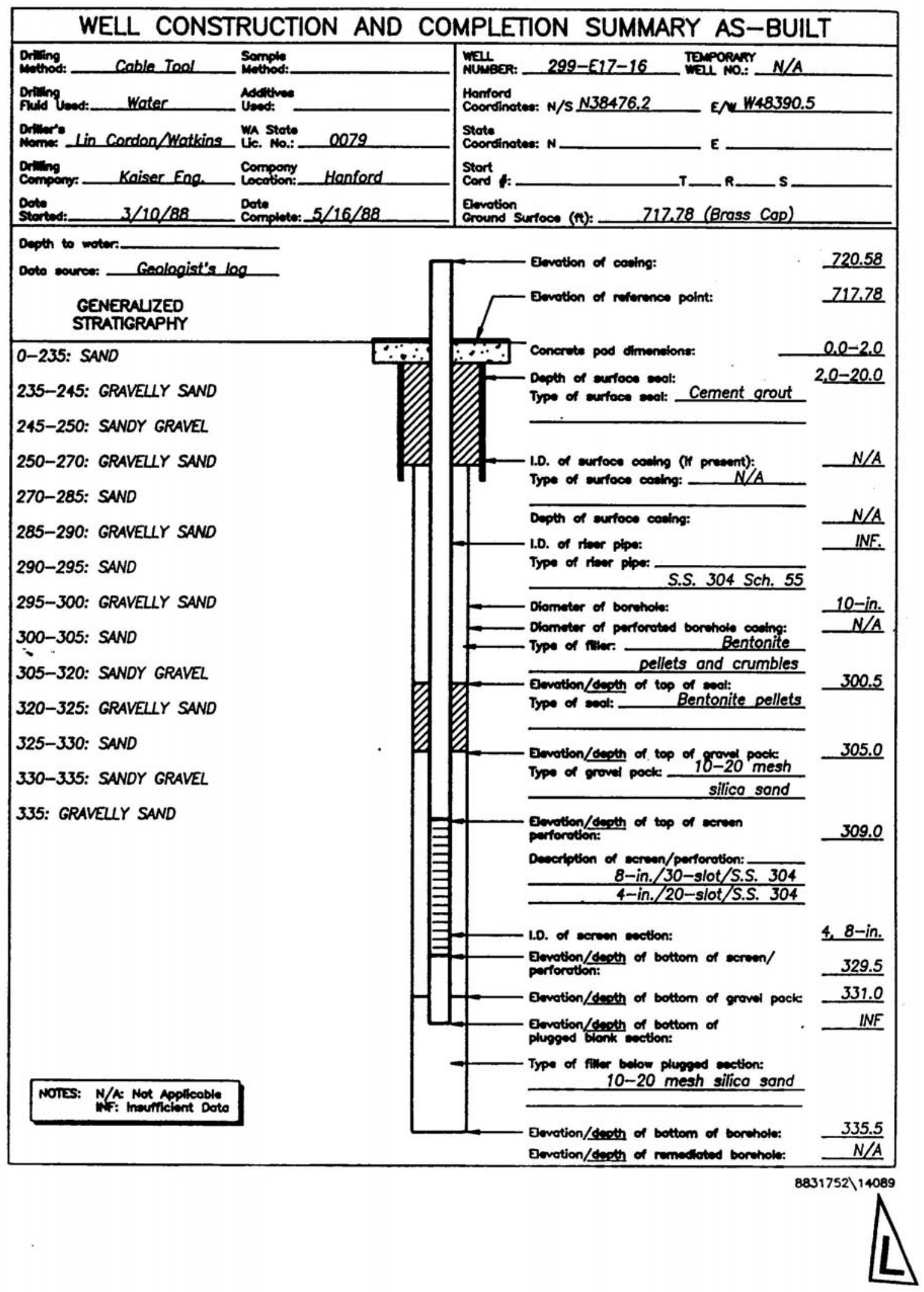

Figure A.3. Well 99-E17-16 Downgradient from A-36B Crib 


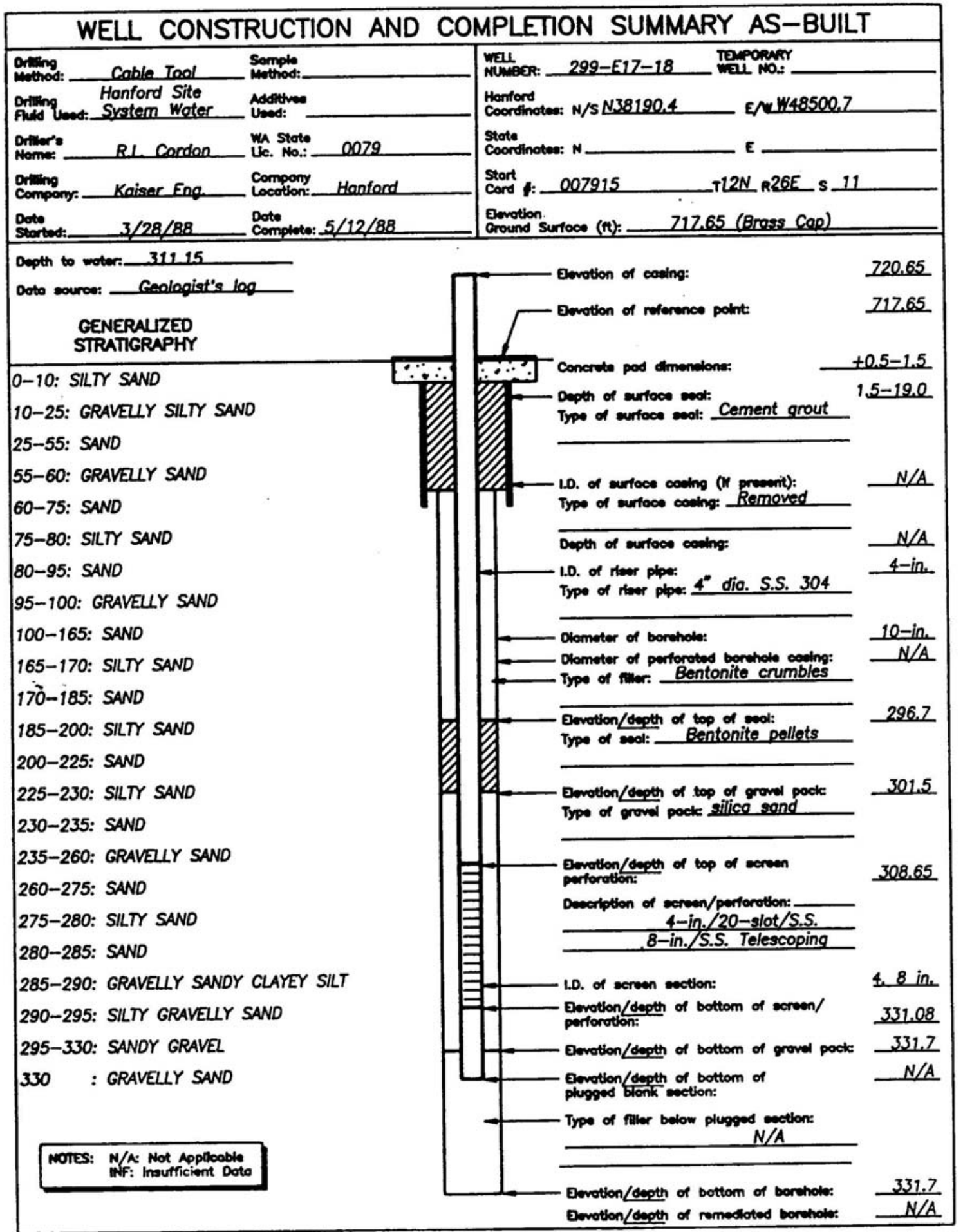

$8031752 \backslash 14091$

Figure A.4. Well 299-E17-18 Downgradient from A-36B Crib 
NON-RECORD COPY

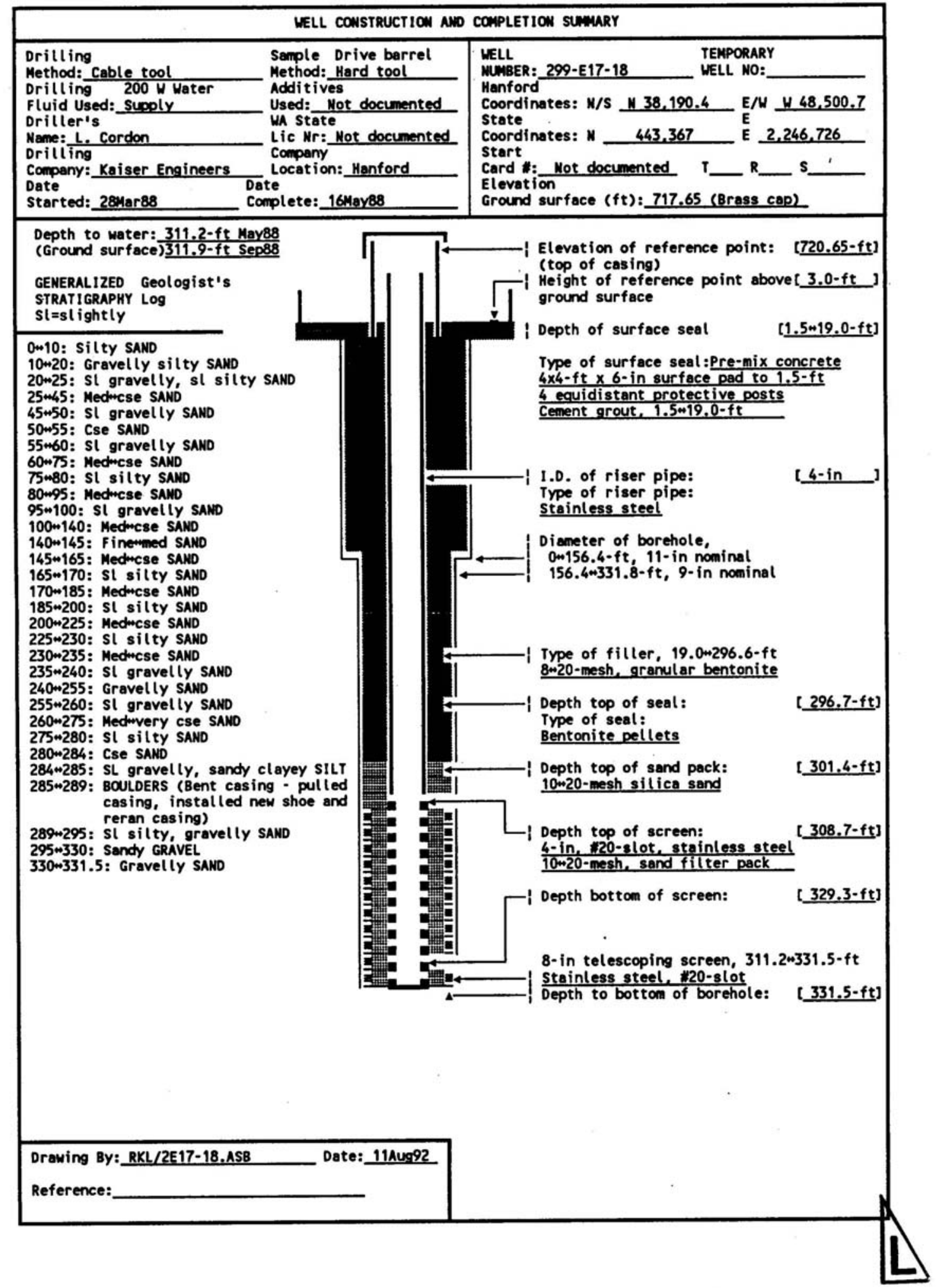

Figure A.4. (contd) 


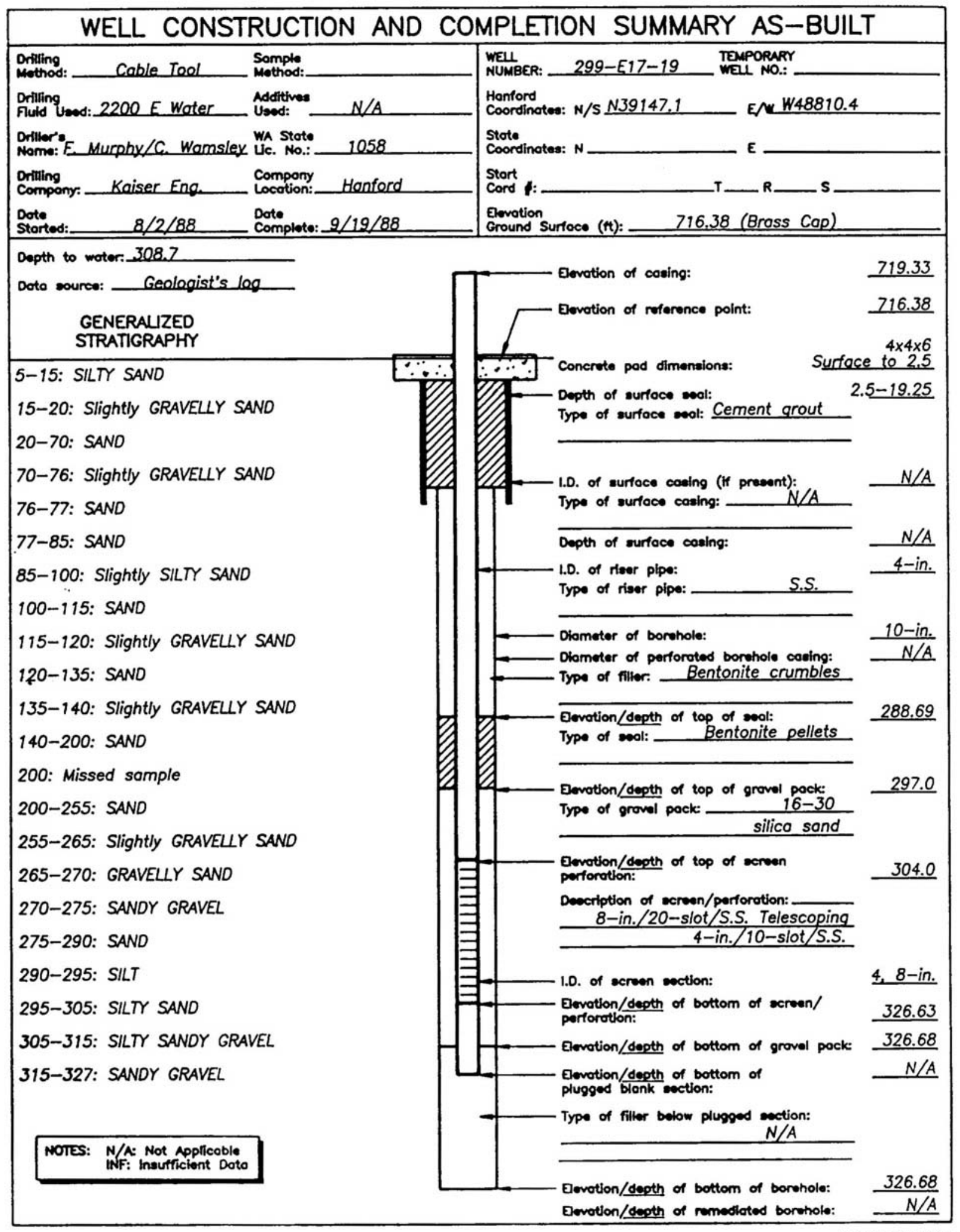

Figure A.5. Well 299-E17-19 Downgradient from A-10 Crib 


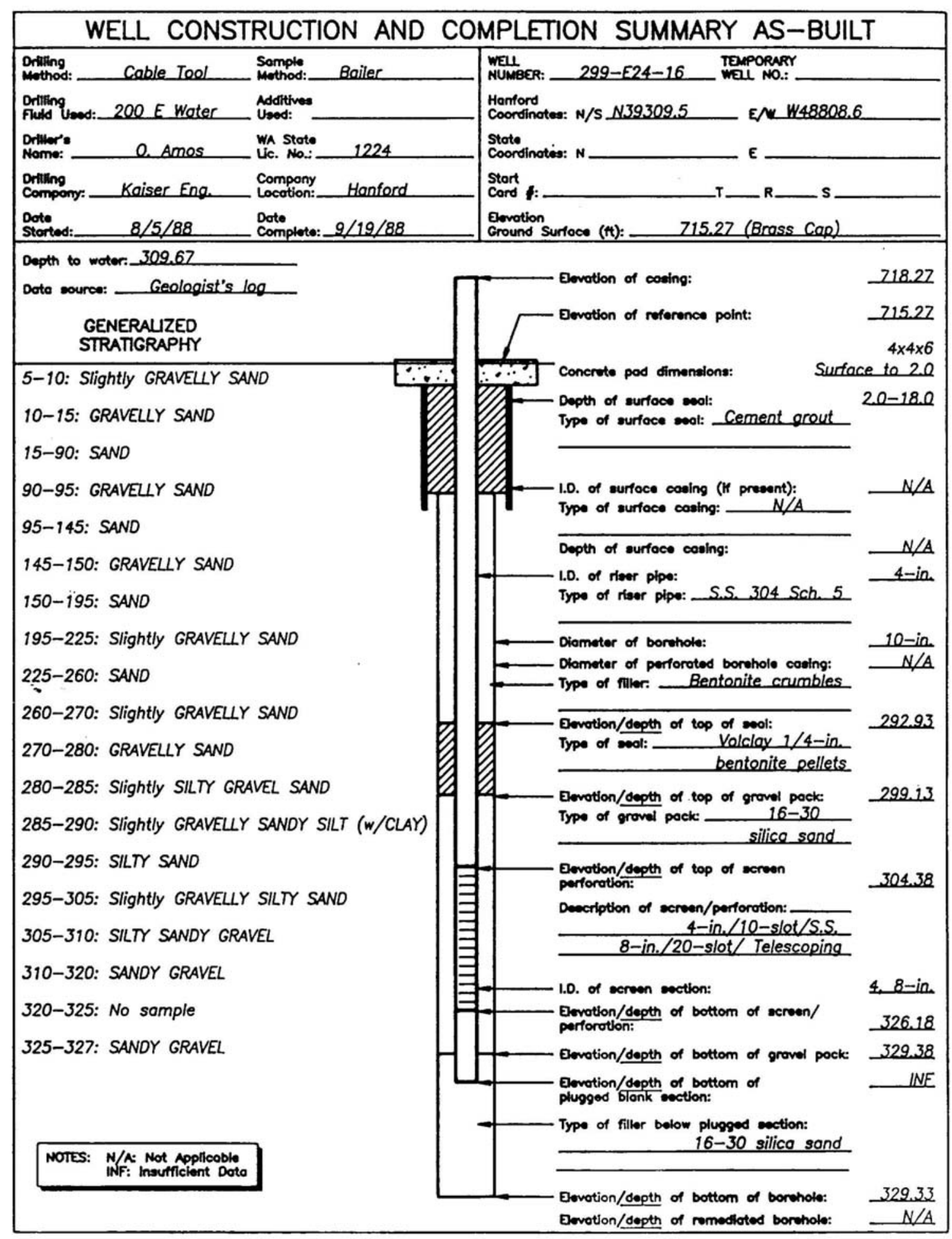

$8831752 \backslash 14099$

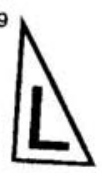

Figure A.6. Well 299-E24-16 Downgradient from A-10 Crib 


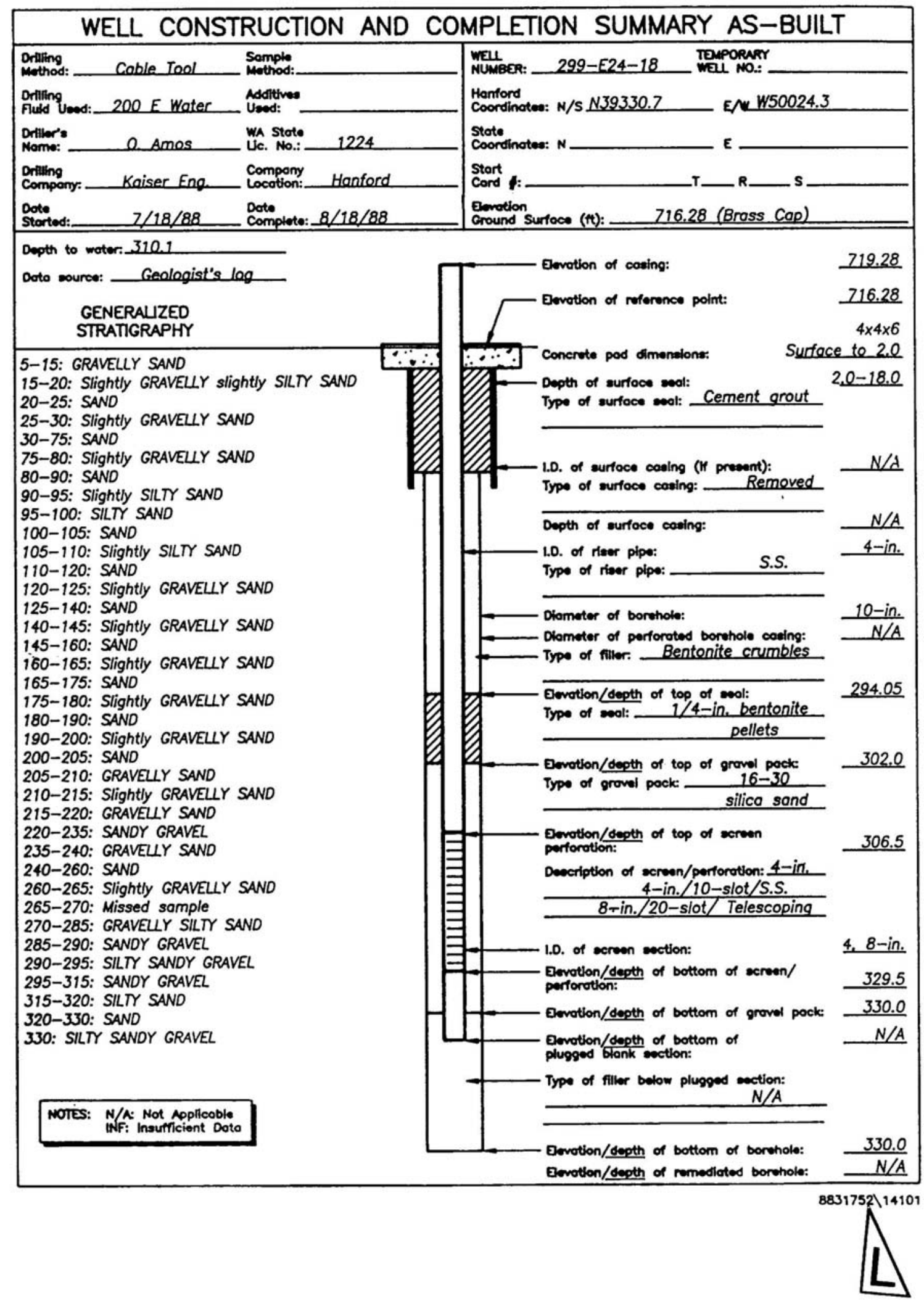

Figure A.7. Well 299-E24-18 Upgradient from A-10 Crib 


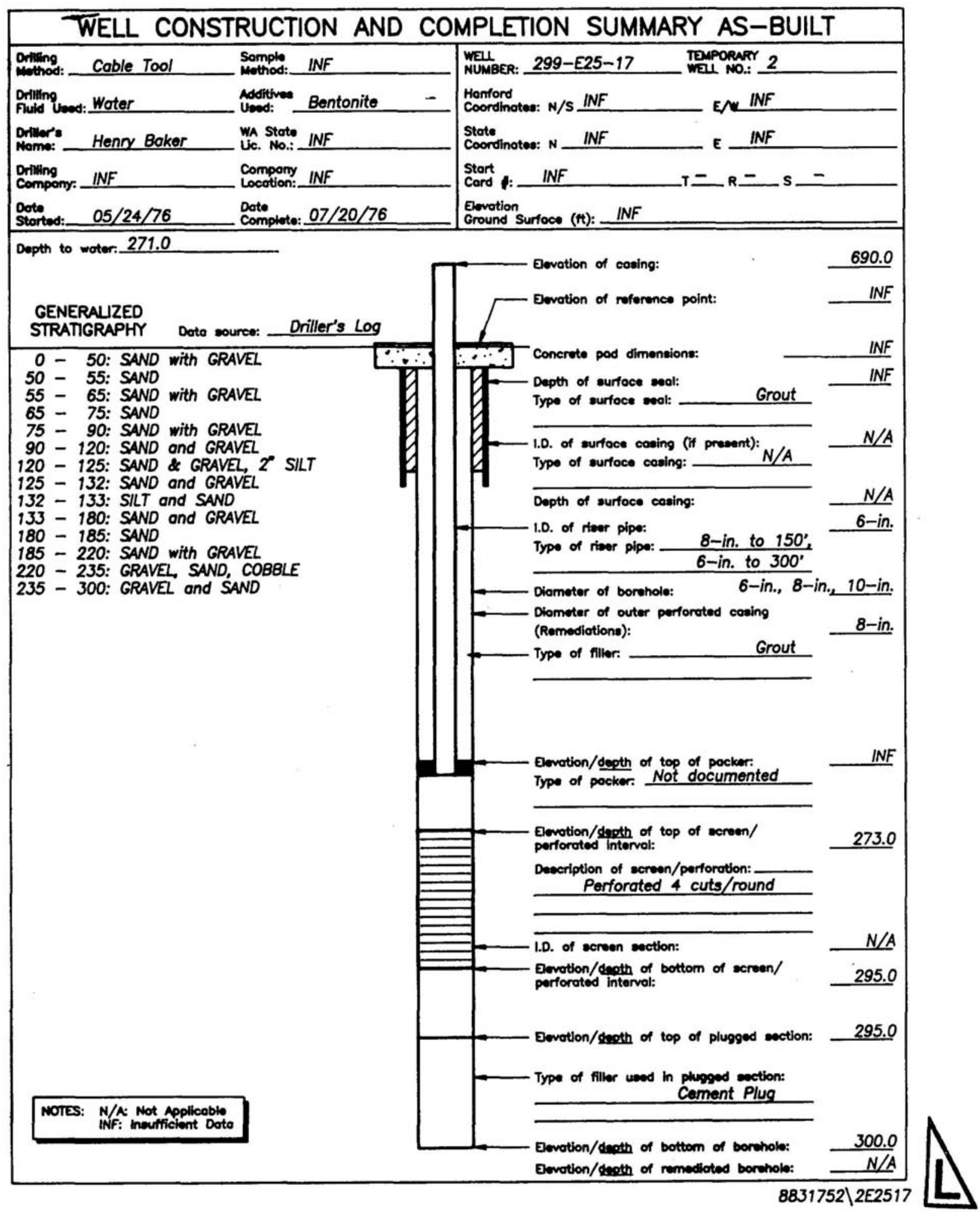

Figure A.8. Well 299-E25-17 Downgradient from A-37-1 Crib 


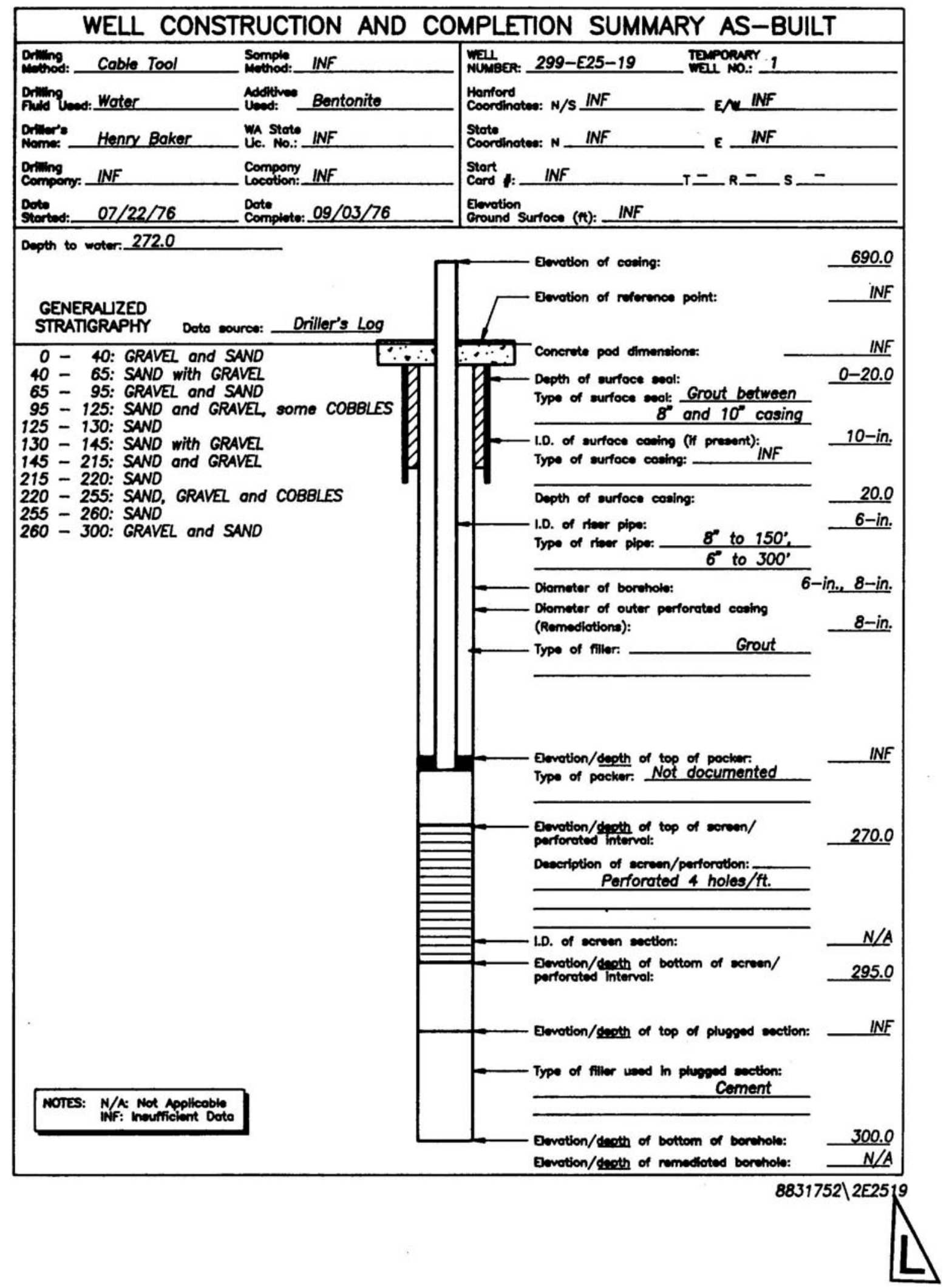

Figure A.9. Well 299-E25-19 Downgradient from A-37-1 Crib 


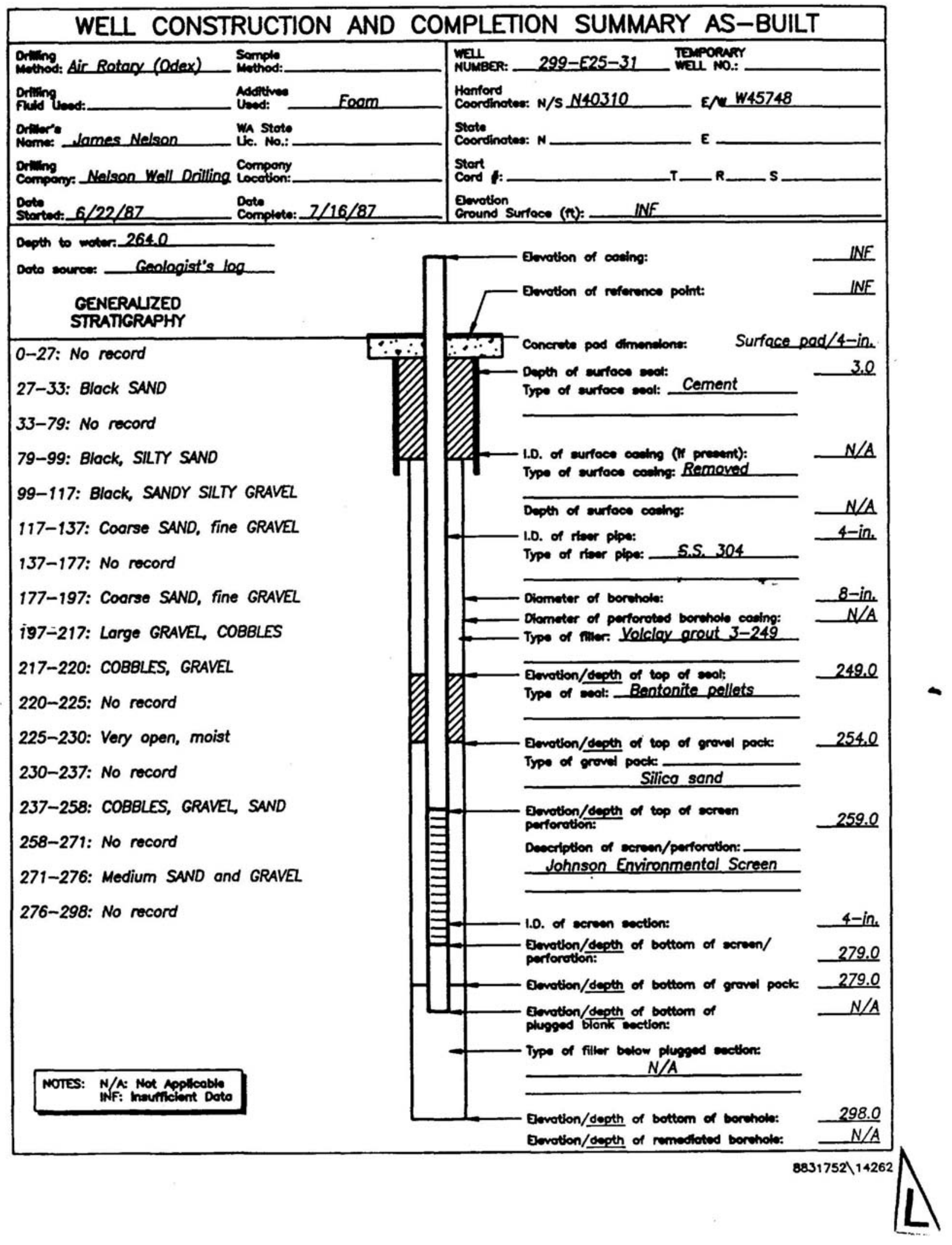

Figure A.10. Well 299-E25-31 Upgradient from A-37-1 Crib 
0534480

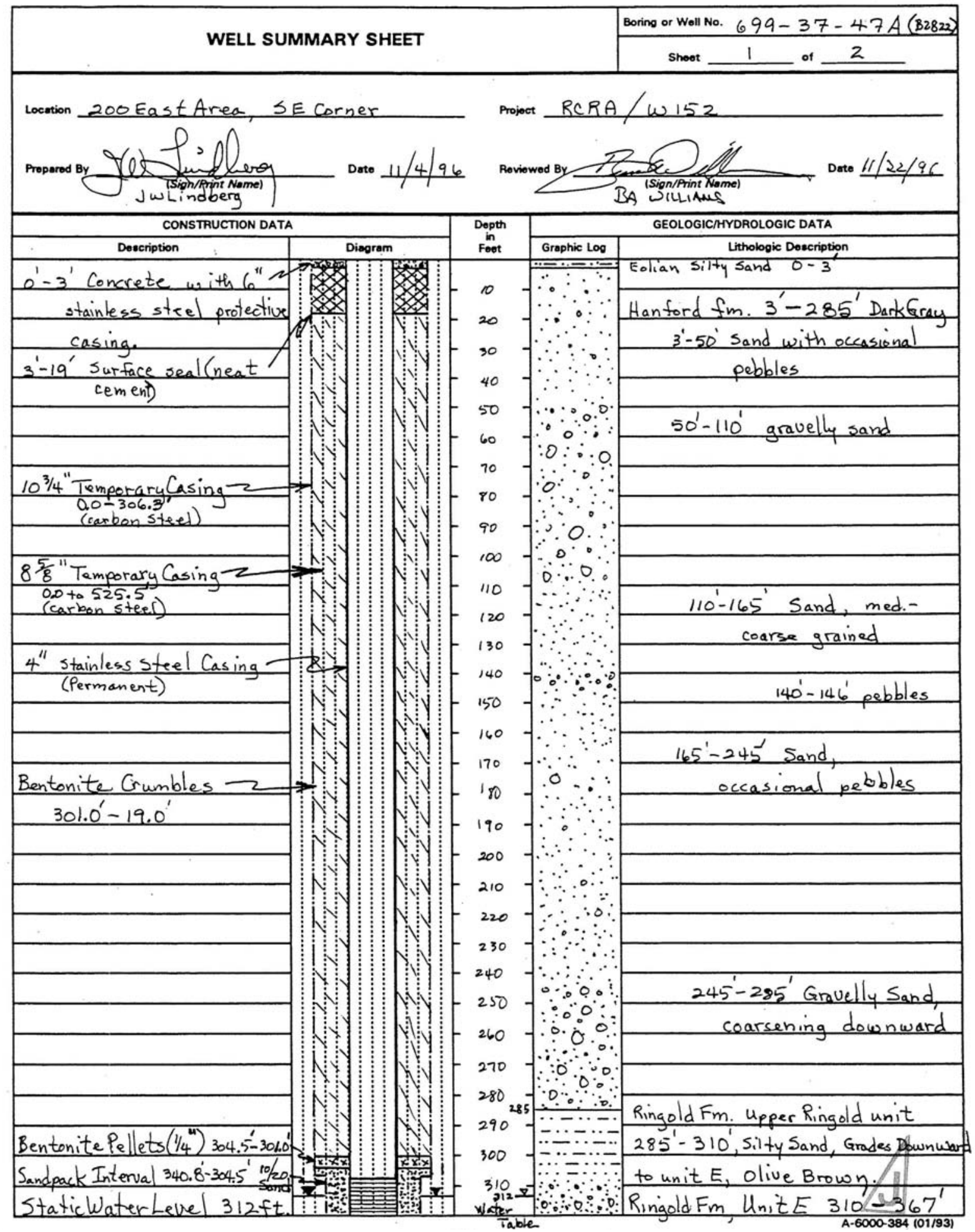

Figure A.11. Well 699-37-47A Downgradient from A-37-1 Crib 


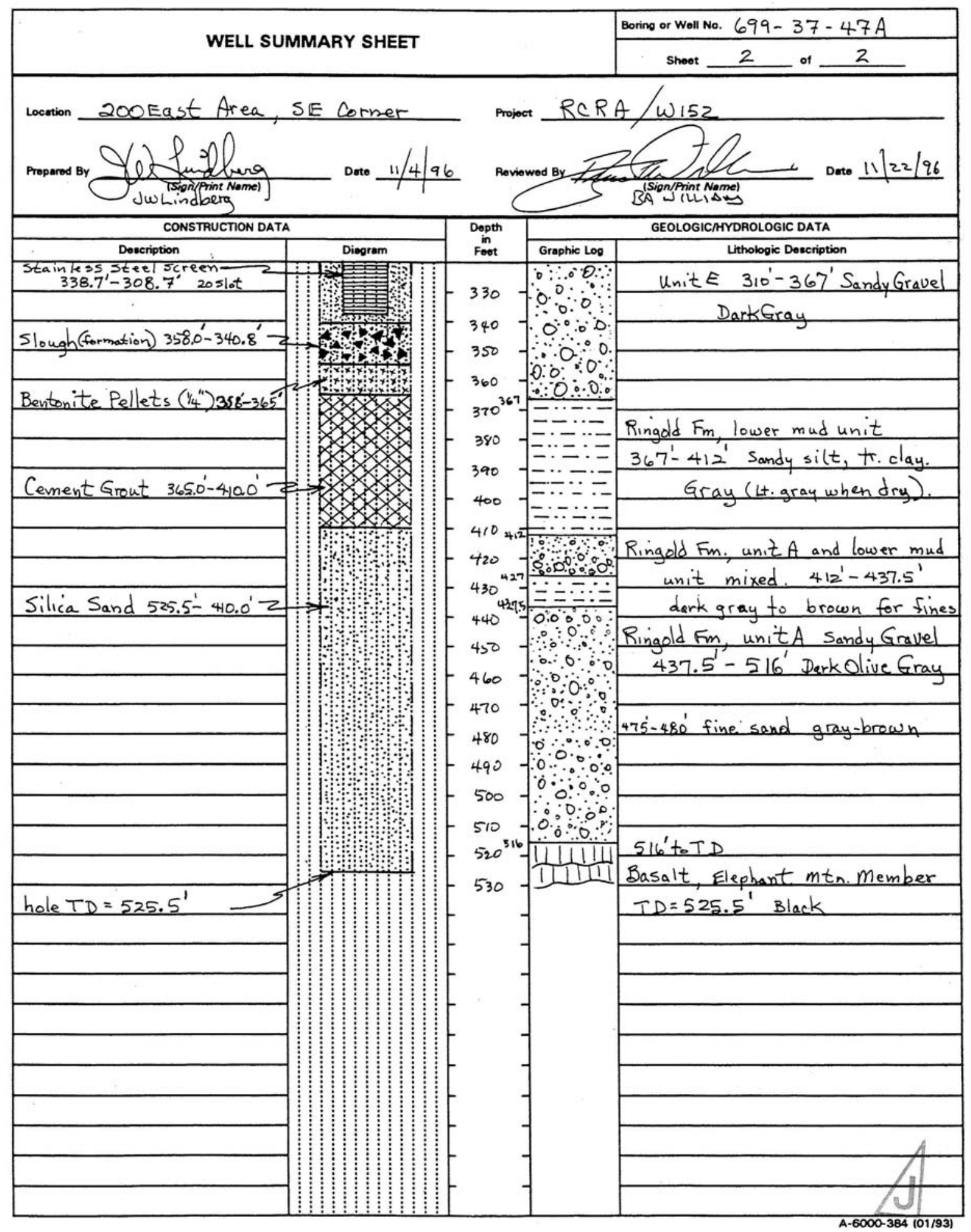

Figure A.11. (contd) 


\section{Distribution}

No. of

Copies

ONSITE

9 DOE, Richland Operations Office

R. D. Hildebrand

A6-38

J. G. Morse

K.M. Thompson

A. Tortoso

Public Reading Room (2)

Administrative Record (2)

5 Fluor Hanford, Inc.

J.V. Borghese

A. Miskho

J.A. Winterhalder

E6-35

H8-40

E6-35
No. of

Copies

18 Pacific Northwest National Laboratory

C.J. Chou

K6-75

R.P. Elmore

K6-96

J.S. Fruchter

K6-96

M.J. Hartman

K6-96

P. Henry

K6-96

J. W. Lindberg (5)

K6-75

S.P. Luttrell

K6-96

D.L. Stewart

K6-96

W.D. Webber

K6-96

Project File

K6-96

Hanford Technical Library (2)

P8-55
3 Washington State Department of Ecology

D. Goswami H0-57

$\mathrm{H} 0-57$ 